This item was submitted to Loughborough's Research Repository by the author.

Items in Figshare are protected by copyright, with all rights reserved, unless otherwise indicated.

\title{
Global factors, uncertainty, weather conditions and energy prices: on the drivers of the duration of commodity price cycle phases
}

\section{PLEASE CITE THE PUBLISHED VERSION}

https://doi.org/10.1016/j.eneco.2020.104862

\section{PUBLISHER}

Elsevier

VERSION

AM (Accepted Manuscript)

\section{PUBLISHER STATEMENT}

This paper was accepted for publication in the journal Energy Economics and the definitive published version is available at https://doi.org/10.1016/j.eneco.2020.104862.

\section{LICENCE}

CC BY-NC-ND 4.0

\section{REPOSITORY RECORD}

Agnello, Luca, Vitor Castro, Shawkat Hammoudeh, and Ricardo Sousa. 2020. "Global Factors, Uncertainty, Weather Conditions and Energy Prices: On the Drivers of the Duration of Commodity Price Cycle Phases". Loughborough University. https://hdl.handle.net/2134/12613034.v1. 


\title{
Global Factors, Uncertainty, Weather Conditions and Energy Prices: On the drivers of the duration of commodity price cycle phases
}

\author{
Luca Agnello $^{*} \quad$ Vítor Castro ${ }^{\dagger} \quad$ Shawkat Hammoudeh $\quad$ Ricardo M. Sousa ${ }^{\S}$
}

\begin{abstract}
We investigate the role of global factors in explaining the length of commodity price cycle phases, using a continuous-time Weibull duration model and data for a panel of 33 countries over the period 1980Q1-2015Q4. We find evidence of increasing (constant) positive duration dependence for commodity price booms and busts (normal time spells). Global macroeconomic conditions - in particular, inflation, economic policy uncertainty and monetary policy actions - significantly affect the duration of all commodity price cycle phases. Global environmental conditions also impact the duration of commodity price booms, with a rise in average temperature (rainfall) increasing (reducing) their length. A rise in the number of military conflicts around the globe is associated with shorter booms and busts. Finally, we find that a rise in oil prices is linked with longer booms and shorter busts.
\end{abstract}

Keywords: commodity price cycles, continuous-time Weibull model, global factors. JEL codes: C41, Q02.

\footnotetext{
* University of Palermo, Faculty of Economics, Department of Economics, Business and Statistics, Viale delle Scienze, 90128 Palermo, Italy. Email: luca.agnello01@unipa.it.

$\dagger$ Loughborough University, School of Business and Economics, Loughborough, Leicestershire LE11 3TU, U.K.; University of Minho, Centre for Research in Economics and Management (NIPE), Campus of Gualtar, 4710-057 - Braga, Portugal. Email: V.M.Q.Castro@lboro.ac.uk.

* LeBow College of Business, Drexel University, 3200 Market Street, Philadelphia, PA 19104, USA.. Email: hammousm@drexel.edu.

$\S$ University of Minho, Department of Economics and Centre for Research in Economics and Management (NIPE), Campus of Gualtar, 4710-057 - Braga, Portugal; London School of Economics and Political Science, LSE Alumni Association, Houghton Street, London WC2 2AE, U.K. E-mails: rjsousa@eeg.uminho.pt, rjsousa@alumni.lse.ac.uk. NIPE's work is financed by the National Funds of the FCT - Portuguese Foundation for Science and Technology within the project "UID/ECO/03182/2019".
} 


\section{Introduction}

The large scale of fluctuations in commodity prices in the first decade of the $21^{\text {st }}$ century have renewed the debate about this issue among academics and policy makers (Loungani, 2009). ${ }^{1}$ Indeed, commodity prices impact earnings of many commodityexporting countries and, thus, have important consequences for external debt, government budget balance, growth prospects, inflation expectations and terms of trade (Arezki and Brückner, 2012). Additionally, they have become an important source of variation even for countries in which the overall share of the commodity sector in the economy is relatively modest (Loungani, 1989; Arezki and Blanchard, 2014).

Yet, while there is a long body of research devoted to the analysis of (the drivers of) world commodity price levels in general (Deaton, 1999), ${ }^{2}$ relevant gaps in our understanding of the properties of commodity price cycle phases, and their length and underlying determinants remain unexplored.

Undoubtedly, cycles are the key feature of the commodity price dynamics (Cashin et al., 2002), which is dominated by prolonged periods of gradual appreciation interrupted by sharp downward corrections (Deaton and Laroque, 1992). Not surprisingly, the literature has employed statistical techniques to identify commodity price cycles, distinguishing between long-term and short-term cycles on the basis of amplitude and duration. This relates to the periodicity of commodity price movements.

Regarding the so-called "super-cycles", the seminal study by Slade (1982) was the first to look at extended, multi-year periods of commodity prices that are significantly higher than their long-run trends (Büyükşahin et al., 2016). ${ }^{3}$ Radetzki (2006) detects three main commodity price booms, including one in the early fifties, another one from the early until the mid seventies, and a final one starting in 2003. Humphreys (2010) shows that the long-lasting metals boom that ran from 2003 to 2008 was triggered by the demand growth in the BRICs (i.e. Brazil, Russia, India and China) due to ongoing industrialization and urbanization. Index fund activity in metals

\footnotetext{
${ }^{1}$ For instance, as Loungani (2009) notes, policies aim at the transition from fossil fuels to other sources of (renewable) energy that increase energy efficiency and attempt to mitigate detrimental environmental effects are desirable, albeit energy independence may not be feasible.

${ }^{2}$ See Labys et al. (1999), Hammoudeh and Yuan (2008), Akram (2009), Belke et al. (2010, 2013, 2014), Humphreys (2010), Arezki and Brückner (2012), Munasinghe et al. (2012), Beckmann et al. (2014), Avalos and Lombardi (2015), Hammoudeh et al. (2015), Ratti and Vespignani (2015) and El-Gamal and Jaffe (2018), who highlight the role played by equity prices, demand growth from emerging markets, geopolitics and violence, global economic prospects, industrial production, inflation, monetary policy and global liquidity, uncertainty, U.S. Dollar fluctuations and weather conditions.

${ }^{3}$ This reflects the fall of the "terms of trade" between primary products and manufactured goods over the very long-term, i.e. the old Prebisch-Singer hypothesis (Arezki et al., 2014a).
} 
commodity markets has also played a role, as institutional investors and speculators increased their commodity exposure (Büyükşahin and Harris, 2011). Erten and Ocampo (2013) highlight that non-oil price super-cycles typically follow world GDP. Erdem and Ünalmis (2016) use different filtering techniques to characterize oil price super-cycles since 1861. They find that, after the nineties, the fast growth rate of emerging economies and the asset price booms in advanced countries fuelled oil demand.

As for the "short-term" cycles, studies have generally relied on higher-frequency (i.e. either monthly or quarterly) data to capture upward and downward trends in commodity prices and date boom-bust episodes. ${ }^{4}$ In the same spirit of the business-cycle literature dated back to Burns and Mitchell (1946), price booms (busts) are described as periods of absolute increases (decreases) in the level of series. For instance, Spatafora and Tytell (2009) stress that the median annual output growth rate is significantly higher during large and long commodity price booms and lower during large busts. There is also a relevant co-movement between oil prices and other (unrelated) commodity prices (Pindyck and Rotemberg, 1990) due to the strong inter-linkages with business cycles and the phenomenon of commodity "financialisation" (Arezki et al., 2014b). ${ }^{5}$

Despite this, several questions populating the empirical literature on commodity prices remain without a conclusive answer. What are the magnitude and duration of commodity price booms, busts and normal times? Does the likelihood of the end of a given phase change as time goes by? In other words, are commodity price cycle phases duration-dependent? What are the crucial determinants of their length?

Against this backdrop, our paper looks at short-term commodity price cycles and uses data for 33 industrialised and emerging markets over the period 1980Q1-2015Q4 to offer a global perspective and fill the above mentioned gaps in the literature.

In this context, our study's objectives and contributions are threefold. First, we identify episodes of booms, busts and normal times in the commodity price cycle and establish a set of stylised facts about the duration of boom-bust phases. For this task, we rely on a novel approach developed and implemented by Agnello et al. $(2015,2017){ }^{6}$

\footnotetext{
${ }^{4}$ Commodity prices are typically subject to persistent shocks (Hamilton, 1989) and display a long-term downward trend (Grilli and Yang, 1988).

${ }^{5}$ For example, in recent times, the high volatility of the stock market due to financial turbulence and economic crises has led to the search for alternative investment instruments as a diversification strategy for stock portfolios (Prokopczuk and Wese Siemen, 2014; Prokopczuk et al., 2017).

${ }^{6}$ As discussed in Section 3, we detect periods of consecutive upturns and downturns in country-specific commodity price indices and build on historical variation to set thresholds of cumulative price growth.
} 
This allows us to explore the transitions across different commodity price phases by empirically assessing their periodicity as compared to the presence of a random walk.

Second, we pay close attention to the length of commodity price booms and busts rather than the occurrence of a specific phase, which makes our work particularly relevant from a welfare perspective. ${ }^{7}$ In doing so, we rely on a continuous-time Weibull duration model to investigate the duration of all commodity price cycle phases and to assess the presence of duration dependence. Hence, we analyse if the probability of a commodity price cycle phase's ending increases/falls as it becomes older.

Third, we quantify the impact of global developments on the length of each commodity price cycle phase. Specifically, we evaluate the effects of global drivers (such as, economic growth, inflation, global liquidity, global activity, global risk perceptions, weather conditions and U.S. monetary policy) on the duration of commodity price booms, busts and normal times.

Our results provide clear evidence of a positive duration dependence in all commodity price cycle phases. Thus, as time goes by, large imbalances in commodity markets tend to be corrected in a return to normal time spells. This corroborates the research supporting commodity price nonlinearities (Sensoy, 2013; Sensoy and Hacihasanoglu, 2014; Salah Uddin et al., 2018a, 2019).

Additionally, global economic conditions and monetary policy are fundamental drivers of the duration of commodity price cycles. Similarly, oil prices prices play an important role in shaping the length of commodity price cycle phases (Salah Uddin et al., 2018a, 2018c).

Concerning commodity price booms, the empirical findings reveal the presence of increasing positive duration dependence, that is, the likelihood of the end of this phase of the commodity price cycle rises (at an increasing rate) as it becomes older. Moreover, higher inflation and an increase in the global temperature are associated with longer booms. By contrast, tighter monetary policy conditions, higher economic policy uncertainty, a rise in military conflicts and an increase in world rainfalls are linked with shorter commodity price booms. All these results suggest that global demand, monetary policy, weather conditions and geopolitical tensions are crucial catalysts of prolonged

\footnotetext{
${ }^{7}$ From a macro-prudential point of view, this distinction is crucial to the extent that movements in commodity prices are associated to changes in macroeconomic variables. For example, the costs of inflation (deflation) associated with a temporary increase (fall) in commodity prices are relatively small, compared to a prolonged commodity prices boom (bust) which can ultimately lead to inflationary (deflationary) spirals. It follows that information on the duration of commodity-price cycles can be used in designing domestic stabilization policies, such as macro-prudential measures (Turner, 2017, 2018).
} 
commodity price appreciations (Frankel, 2006; Akram, 2009; Gilbert, 2010; Munasinghe et al., 2012). Commodity price booms also tend to be longer in developed countries than in emerging markets.

As for the commodity price busts, we also find increasing a positive duration dependence. However, only global economic factors significantly affect their length, with the direction of the impact being opposite to that of booms. Thus, the collapse of commodity prices moves in tandem with the deterioration of the world economic activity, unfavourable climate changes and military conflicts (Frankel and Rose, 2010; Auffhammer and Schlenker, 2014; Raleigh et al., 2015; Carleton and Hsiang, 2016). Commodity price busts have become shorter over time, but no significant difference in length is observed between OECD and non-OECD countries.

Finally, normal time spells display a positive duration dependence. They are shortened when global inflation increases, and prolonged when global monetary policy conditions are tightened, global liquidity increases, and military conflicts and uncertainty rise. The length of normal time spells has fallen over time and their likelihood to end is higher in emerging markets than in industrialised countries.

The evidence reported in our study is robust to: (i) a different uncertainty measure; (ii) a broader set of control variables; and (iii) alternative identification schemes for commodity price cycle phases.

All in all, our paper yields some key implications for investors and policymakers. In one hand, estimating the duration of commodity price booms, measuring the severity of commodity price busts and identifying the global factors behind normal time phases lay at the heart of any meaningful analysis of investment activity. On the other hand, commodity price fluctuations and the quick transition from boom to bust episodes pose major challenges for policymakers by negatively affecting the stabilisation capacity of central banks and governments and potentially disrupting financial markets (Sensoy et al., 2014; Hammoudeh et al., 2015). Hence, our results can help investors in the design of portfolio strategies that maximise diversification benefits from exposure in commodities. Since a prompt policy response requires a good understanding of commodity price cycles, they can also enhance the efficacy of countercyclical measures by providing policymakers with a framework that spurs welfare gains.

The rest of this paper is organised as follows. Section 2 details the econometric strategy. Section 3 describes the data. Section 4 discusses the empirical results. Finally, Section 5 concludes. 


\section{Econometric Methodology}

In the same spirit of the works by Sichel (1991), Castro (2010, 2013) and Agnello et al. (2013, 2015, 2017, 2018, 2019), we consider hazard-based duration models $^{8}$ to test for duration dependence in the commodity price cycle phases (i.e. booms, busts or normal times) and to assess the role of global drivers on the length of such phases. ${ }^{9}$

Assume that $T$ is a non-negative continuous random variable that measures the time span between the beginning and the end of a commodity price cycle phase with the probability distribution $F(t)=\operatorname{Pr}(T<t)$ and the survival function given by $S(t)=\operatorname{Pr}(T \geq t)$ $=1-F(t)$. Denoting the density function by $f(t)$, we can write the hazard function as $h(t)=f(t) / S(t)$, which corresponds to the conditional probability of a commodity price cycle phase ending at time $t$, given that it lasted until that point in time.

The sign of the derivative of $h(t)$ with respect to $t$ characterises duration dependence, that is, we have: (i) positive duration dependence, if $\mathrm{d} h(t) / \mathrm{d} t>0$; (ii) negative duration dependence, if $\mathrm{d} h(t) / \mathrm{d} t<0$; and (iii) no duration dependence, if $\mathrm{d} h(t) / \mathrm{d} t=0$. Positive (negative) duration dependence means that the probability of a commodity price cycle phase ending increases (decreases) as time passes by.

Given its ability to accommodate the effect of time-varying covariates, a popular parametric form for the hazard function is the proportional hazard model:

$$
h(t, x)=h_{0}(t) \exp (\mathbf{x} \boldsymbol{\beta})
$$

where $h_{0}(t)$ is the baseline hazard function, $\boldsymbol{\beta}$ is a $(\mathrm{k} \times 1)$ vector of parameters to be estimated, and $\mathbf{x}$ is a vector of time-invariant covariates. By imposing a parametric functional form on the baseline hazard, $h_{0}(t)$, we obtain the Weibull model: ${ }^{10,11}$

\footnotetext{
${ }^{8}$ Instead of hazard-based duration models, one could use binary dependent regression models (e.g. logit, probit...) by simply modeling whether a specific commodity price cycle phase (e.g. boom, bust or normal time) transits to a different phase or not. In this case, observations with a transition would be equal to 1 and censored observations would be equal to 0. However, according to Jenkins (2005), these models bring some problems, namely: (i) they do not account for time-varying differences in the risk that each unit of observation experiences the event of interest; (ii) a large number of observations is lost, especially when the unit of observation leaves the current state (if this actually happens); (iii) cross-tabulations of survival times against some categorical/categorised variable cannot be used for inference about the relationship between survival time and that variable; and (iv) for the same reason, the dependent variable is mis-measured and censoring is not accounted for.

${ }^{9}$ For theoretical details and empirical applications of duration models, see Kiefer (1988), Allison (2014) and Agnello et al. (2017, 2018).

${ }^{10}$ The proportional hazard model - where we assume that the relative risk of an event is constant over time - could be estimated without imposing any specific functional form on the baseline hazard function (i.e., the so-called "Cox model"). However, this model does not allow for the estimation of the duration dependence parameter, which is crucial for our analysis. Additionally, in the case of large datasets like ours, Hess and Persson (2010) note that the Cox model may be inadequate, due to the lack of appropriate
} 


$$
h_{0}(t)=\gamma p t^{p-1}
$$

where $\gamma$ is a constant and $p$ is a non-negative parameter that describes the nature of duration dependence, that is: a value of $p$ greater (lower) than 1 implies the presence of positive (negative) duration dependence; and if $p$ is equal to 1 , there is no duration dependence. Substituting (2) for $h_{o}(t)$ into (1), we obtain:

$$
h(t, \mathbf{x})=\gamma p t^{p-1} \exp (\mathbf{x} \boldsymbol{\beta}) .
$$

Based on this function, we can derive the integrated hazard function, $H(t)=\int_{0}^{t} h(u) d u$, and obtain the survival function, $S(t)=\exp [-H(t)]$ or $S(t, \mathbf{x})=\exp \left[-\gamma^{p} \exp (\mathbf{x} \boldsymbol{\beta})\right]$.

Finally, the model is estimated by the Maximum Likelihood, with the loglikelihood function for a sample of commodity price booms, busts or normal time spells is given by:

$$
\begin{aligned}
\ln L(\cdot) & =\sum_{i=1}^{n}\left[c_{i} \ln h\left(t_{i}, \mathbf{x}_{i}\right)+\ln S\left(t_{i} \mathbf{x}_{i}\right)\right]= \\
& =\sum_{i=1}^{n}\left[c_{i}\left(\ln \gamma+\ln p+(p-1) \ln t_{i}+\mathbf{x}_{i} \boldsymbol{\beta}\right)-\gamma t_{i}^{p} \exp \left(\mathbf{x}_{i} \boldsymbol{\beta}\right)\right],
\end{aligned}
$$

where $i=1, \ldots, n, c_{i}=0$, if the sample period under analysis ends before the transition between the two events has been observed (i.e. observations are censored); and $c_{i}=1$, if such transition is observed in the sample period (i.e. observations are not censored).

\section{Data}

We consider 33 developed and emerging markets for which data on countryspecific commodity export prices are available over the period 1980Q1-2015Q4. ${ }^{12,13}$

\footnotetext{
control over unobserved heterogeneity and the restrictive assumption of proportional hazards. Moreover, point coefficient estimates (and corresponding standard errors) may be biased, especially when duration times are tied. For these reasons, we opt for the "Weibull model", which imposes a specific parametric form on the baseline hazard function.

${ }^{11}$ Jenkins (1995) and Rodríguez (2010) highlight that other distributions can be considered, including exponential, generalized Gamma, Gompertz, log-logistic, log-normal or no parametric specification for the baseline hazard function (i.e. the Cox model). We confirm the suitability of the Weibull distribution via the assessment of the Akaike (AIC) and Bayesian information criteria (BIC). Indeed, this distribution was almost always the one that minimised AIC and BIC and maximised the log-likelihood function. These results are not reported in the paper, but they are available from the authors upon request.

${ }^{12}$ The list of countries included in the analysis for which commodity export price data are readily available is as follows: Argentina, Australia, Brazil, Canada, Chile, China, Colombia, Denmark, Finland, Hungary, Iceland, India, Indonesia, Israel, Republic of Korea, Malaysia, Mexico, New Zealand, Norway, Peru, Philippines, Poland, Romania, Slovak Republic, Russia, South Africa, Spain, Sweden, Switzerland, Thailand, Turkey, the UK and the US.

${ }^{13}$ As noted by Kohlscheen et al. (2017), these indices are timely proxies for a country's terms of trade. They are based on 3-digit UN Comtrade data, mainly sourced from exchange markets (such as, the Chicago Mercantile Exchange (CME) and the London Metal Exchange (LME)), and cover market prices
} 
A description of all variables is presented in Table 1. Some of the global macroeconomic conditions are proxied by the US variables, which includes the real GDP growth rate (RGDPgr), the inflation rate (Inflation), the interest rate (InterestRate) and the economic policy uncertainty (EPU) index (Uncertainty). ${ }^{14}, 15$ Other global factors include: (i) global liquidity (Liquidity); (ii) the number of military conflicts around the globe (Violence); (iii) world average temperature (Temperature); and (iv) world average rainfall (Rainfall).

Finally, we account for the potential differences in the length of commodity price cycle phases between high-income (OECD) and other countries by considering a HighIncome $(O E C D)$ dummy variable, which takes the value of one if a country is a high-income (OECD) country, and zero otherwise. We also investigate the importance of regional effects by including the following dummies: (i) $A F R$, i.e. Africa (the reference group); (ii) EAP, i.e. East Asia and Pacific; (iii) ECA, i.e. Europe and Central Asia; (iv) LAC, i.e. Latin America and the Caribbean; (v) MENA, i.e. Middle East and North Africa; (vi) NAM, i.e. North America; and (vii) SAS, i.e. South Asia. Income and regional groups are categorized in accordance with the World Bank's classification.

\section{[Insert Table 1 here]}

In what concerns the method used in the identification of episodes of booms, busts and normal times episodes in the commodity price cycle, we remark that a commonly accepted framework does not exist in the empirical literature. Yet, it should be simple, fairly objective and produce plausible results (Agnello and Schuknecht, 2011). ${ }^{16}$ Thus, we use a novel approach developed and implemented by Agnello et al.

\footnotetext{
for 83 commodities: 36 agricultural commodities, 10 energy commodities, 11 livestock commodities and 26 metal commodities. They are constructed as Laspeyres indices, with the weight of each commodity in the country's basket matching its export revenues' share in total commodity export revenues.

${ }^{14}$ Alternatively, one could use data for the world's GDP growth rate, inflation rate and interest rate using the World Development Indicators (WDI) database of the World Bank (WB). However, these series are only available annually and the covered time span is shorter. For the same reason, we do not consider the global EPU index. In addition, Ratti and Vespignani (2016) show that the U.S. - and also the euro area and China - are the key engines of global macroeconomic conditions.

${ }^{15}$ Prokopczuk et al. (2019) find a strong co-movement commodity market volatility and economic and financial uncertainty, in particular, during recession episodes. Salah Uddin et al. (2018b) also show that geopolitical uncertainty has a strong, albeit heterogeneous, impact on crude oil markets.

${ }^{16}$ Different non-parametric approaches have been proposed. For instance, with reference to asset price series, Bordo and Jeanne (2002) and Borio and Lowe (2002) identify boom and busts when the three-year moving average of the growth rate falls outside a confidence interval defined with reference to the historical first- and second-moments of the series. Detken and Smets (2004) and Adalid and Detken (2007) detect asset price booms as periods in which real asset prices lie more than $10 \%$ above an estimated trend recursively calculated using a one-sided Hodrick-Prescott filter with a very large smoothing parameter.
} 
$(2015,2017){ }^{17}$ In this context, the quarterly real growth of the country-specific commodity export price index is smoothed using an (equally-weighted, five-quarter) centred moving average. Then, we detect periods of consecutive upturns (i.e. positive growth) and downturns (i.e. negative growth) in the smoothed series, thus, dating its turning points (i.e. peaks and troughs). Next, we build on the historical variation across either all periods of consecutive upturns or downturns to set (average) thresholds of (cumulative) real commodity export price growth. Finally, if a cumulative growth over any given period of consecutive upturns (downturns) exceeds (falls below) a minimum (maximum) bound, it is labelled as a boom (bust); all other (upturn and downturn) episodes denoting cumulatively small fluctuations in commodity export prices are identified as normal times. Using this procedure, we identify commodity price booms (busts) as periods of consecutive upturns (downturns) in the real country-specific commodity export index amounting to $18 \%(-25 \%)$ cumulatively.

By organizing the data in spells, we are able to identify 97 episodes of commodity price booms, 136 episodes of commodity price busts and 169 normal time spells. ${ }^{18}$ Details on their characteristics are reported in Table 2. A summary of the descriptive statistics for all the other variables included in the empirical analysis can also be found in this table.

\section{[Insert Table 2 here]}

In Figure 1, we also plot the survival function for the commodity price booms (top-left panel), the busts (top-right panel) and the normal times (bottom-centre panel). It can be seen that the probability of a commodity cycle phase surviving after a certain duration substantially decreases over time. Thus, in the next Section, we empirically assess if this decline is consistent with the presence of duration dependence.

[Insert Figure 1 here]

\section{Empirical Findings}

In this Section, we discuss the results of the continuous-time Weibull model. Specifically, in Section 4.1 we present results for the commodity price boom phase. In

\footnotetext{
${ }^{17}$ Agnello et al. $(2015,2017)$ rely on this framework to establish housing price cycle phases. Alberola and Sousa (2017) use it to identify the commodity price cycle phases in 12 resource-rich countries, but the aim is to quantify the impact of the commodity price cycle on the characterisation of episodes of fiscal consolidation and stimulus and the size of the fiscal impulse.

${ }^{18}$ The duration of booms (busts) ranges from 4 (5) quarters to 25 (31) quarters and its mean is of nearly 12 (13) quarters. Normal time spells have an average duration of 11 quarters with a length that varies between one quarter and 70 quarters. Finally, commodity booms and normal time spells (commodity busts) tend to be slightly longer (shorter) in OECD countries than in non-OECD countries.
} 
Section 4.2, we report the empirical findings for the commodity price bust phase, and in Section 4.3 we provide the results for the normal time spells. In Section 4.4., we analyse the impact of oil/energy prices on the duration of commodity price phases. Finally, in Section 4.5 , we report the sensitivity analysis.

\subsection{Commodity price booms}

The empirical results from the estimation of the continuous-time Weibull model for the duration of commodity price booms are presented in Table 3 and discussed in this Section. For each regression - apart from the estimated coefficients and corresponding robust standard errors -, we report the number of spells, the loglikelihood function $(\log L)$, the Schwarz Bayesian Information Criterion (SBIC) and the Likelihood Ratio statistics $(L R)$ that test for the presence of frailty and country effects.

A one-sided test is used to detect the presence of the positive duration dependence (i.e., whether $\mathrm{p}>1$ ), and the sign "+" indicates significance at the $5 \%$ level. The results corroborate this hypothesis for commodity price booms, which means that the likelihood of a boom ending increases as the time goes by. This is valid for the basic Weibull model estimated in Column 1, but also for other variants/extensions reported in Table 3. Moreover, in most of the cases, $p$ is significantly higher than 2, which implies the presence of increasing positive duration dependence. ${ }^{19}$ This means that the probability of commodity price booms ending at time $t$, given that they lasted until that moment, increases over time at an increasing rate.

In Column 1, we assume that commodity price booms may last from one quarter to the maximum number of time periods that are observable in our sample. However, the descriptive statistics show that their minimum duration is four quarters. Hence, in Column 2, we assess whether truncating booms at their minimum duration affects the results or not. This implies that the hazard rate must be zero for the first four quarters and some nonzero value thereafter. The results are not sensitive to the choice of the minimum observable duration. Therefore, in line with Sichel (1991) and Castro (2010, 2013), we proceed with the analysis avoiding this redundant technical complexity.

So far, we have assumed that the population of individual spells is homogeneous, as each boom is supposed to be at the same risk of ending. Given that this may not be a good description of reality, the estimation reported in Column 3

\footnotetext{
${ }^{19}$ For details on the speed of the duration dependence process, see Castro $(2010,2013)$.
} 
allows for the presence of unobserved heterogeneity or frailty. ${ }^{20}$ The LR-test presented at the bottom of the table confirms its presence. ${ }^{21}$ This might be due to the fact that we do not account for additional observables or unobserved individual or time effects. Hence, in Column 4, we add regional dummies and decade dummy variables. ${ }^{22}$ By proceeding in this way, we do not compromise within-groups variability of regressors (see Column 5 in Tables 3-4). The coefficients on regional effects are highly significant and we also observe that commodity price booms became longer in the first decade of the millennium.

The model is extended in Column 5 by adding a set of time-invariant control variables like: $(i)$ a trend variable (Event), which measures the order of the event over time; (ii) a dummy that is equal to one if the previous phase was a normal time spell, and zero otherwise (Prev); and (iii) the duration of the previous phase (DurPrev). Although none of these variables is statistically significant, their inclusion in the model does not undermine the evidence of the positive duration dependence.

\section{[Insert Table 3 here]}

In Table 4, we extend the model with the inclusion of the global factors that are expected to influence the duration of commodity price phases (see Section 3). As the model only allows for time-invariant regressors, all variables are measured as averages over each spell. Columns 1 and 2 report the results with these additional variables, where regional and decade effects are accounted for (they are not reported to save space, but they generally remain statistically significant).

Despite the fact that the commodity price booms still show an increasing propensity to end as they grow older, their duration is also significantly affected by all additional regressors. Specifically, booms tend to be longer when inflation and temperature increase. By contrast, booms are shorter due to increases in the interest rate,

\footnotetext{
${ }^{20}$ In a frailty (random-effects) model for duration analysis, an unobserved random proportionality factor modifies the hazard function of the exit spell to account for the heterogeneity due to measurement error or unmeasured covariates, that is: $\mathrm{h}(\mathrm{t}, \mathbf{x} \mid v)=v \cdot \mathrm{h}(\mathrm{t}, \mathbf{x})$, where $v$ is a (positive) random variable with unity mean, finite variance $(\theta)$, and independently distributed from $t$ and $\boldsymbol{x}$, and captures the unobserved individual-spell effect that scales the no-frailty component, and is. Since $v$ is unobserved, we assume that it follows an inverse-Gaussian distribution with unity mean and variance $1 / \theta$, that is: $\mathrm{h}(\mathrm{t}, \mathbf{x} \mid v)=\mathrm{h}(\mathrm{t}, \mathbf{x}) \cdot[1-$ $2 \theta \operatorname{lnS}(\mathrm{t}, \mathbf{x})]^{-1 / 2}$ (see Lancaster (1990) and Gutierrez et al. (2001)).

${ }^{21}$ For details on the LR-test, see Gutierrez et al. (2001).

${ }^{22}$ Country-specific dummy variables could be considered instead as a way of avoiding the (unobserved) heterogeneity issue. While we have used them in experiments not reported in the paper for brevity, we note that with a limited number of spells per country, country-specific effects may have to be ruled out, as they undermine the variability of regressors when additional covariates are added to the model. Hence, to simplify the analysis, we use regional dummy variables. For more details, see Claessens et al. (2011).
} 
liquidity, uncertainty, violence and rainfall. ${ }^{23}$ For example, a one percentage point rise in the uncertainty index is associated with a fall in the likelihood of a commodity price boom ending of around $20 \%$.

This means that easing monetary policy conditions and favourable weather conditions pave the way for longer periods of booms in commodity prices. Additionally, as high temperatures and droughts affect the production of agricultural commodities, the overall price of commodities is pushed upwards and above its normal level; and the boom may remain for longer, the worse environmental conditions are, suggesting an important effect on the supply-side of commodity market conditions. ${ }^{24}$

Summing up, global demand, monetary policy, weather conditions and geopolitical tensions are important determinants of large and sustained commodity price appreciations (Frankel, 2006; Akram, 2009; Gilbert, 2010; Munasinghe et al., 2012). Thus, monetary policy tightening can counteract the potentially deleterious impact of commodity price booms.

We also account for the role of countries' income levels by distinguishing between high-income and low-income countries. The dummy variable HighIncome is included in Column 3 to account for this effect, but no significant difference is found. However, when a dummy for OECD versus non-OECD countries is used, a relevant difference is found; that is, commodity price booms are, on average, longer in OECD countries that in non-OECD countries. This result provides a statistical confirmation for the difference identified in the descriptive statistics for booms (see Table 2).

Therefore, we investigate the differences in the duration dependence dynamics between OECD and non-OECD countries by splitting the sample in these two groups and estimating the model separately. The results are reported in Columns 5 (nonOECD) and 6 (OECD). They show that RGDPgr, Liquidity, Temperature and Rainfall (InterestRate and Violence) matter more in explaining the duration of booms in OECD (non-OECD) countries than in the other group. Most importantly, the estimates for the

\footnotetext{
${ }^{23}$ For details on the interpretation of the estimated coefficients, see Allison (2014). In particular, $100(\exp (\beta)-1)$ gives the percentage change in the hazard for each unit change in the respective explanatory variable.

${ }^{24}$ We also consider the three quartiles of the distribution (i.e. percentiles 25,50 (median), and 75) given that simple averages for global temperature and rainfall might miss relevant information. For commodity price booms, the empirical findings remained broadly unchanged when compared to those in Column 2 of Table 4. Similar results are uncovered for commodity price busts and normal times. For brevity, they are not reported here, but are available from the authors upon request. In this context, Sensoy et al. (2015) show that the physical supply/demand balance is a key driver of commodity futures prices. Salah Uddin $e t$ al. (2018c) find that demand and supply shocks have a positive effect on precious metal returns, but risk shocks have a negative impact.
} 
duration dependence parameters show that booms approach their end faster in nonOECD countries (6.359) than in OECD countries (5.726), corroborating the evidence that booms are shorter in emerging markets compared to developed countries.

To assess if this difference in the duration dependence parameter is statistically significant or not, we change the structure of the (baseline) hazard function to account for the $O E C D$ dummy variable: $h(t, \mathbf{x})=\gamma(p+\Delta p \cdot O E C D) t^{(p+\triangle p \cdot O E C D)-1} \exp (\mathbf{x} \boldsymbol{\beta})$. This means that $p$ will measure the duration dependence for the non-OECD countries, while $p+\Delta p$ will be the duration dependence parameter for the OECD countries; hence, $\Delta p$ is the estimated difference in the duration dependence parameter between the two groups. The results reported in Column 7 show a significant difference in the duration dependence parameter. That is, it is statistically lower for the OECD countries, which implies a lower propensity for booms ending over time (i.e. longer booms) compared to the other group. However, the evidence of increasing duration dependence is common to both groups. The inclusion of the OECD dummy as an additional regressor (see Column 8) neither changes this evidence, nor provides any additional relevant information. This might be an indication that commodity price booms in OECD are longer because their dynamics over time and until maturity are slower than in the other countries.

[Insert Table 4 here]

\subsection{Commodity price busts}

A similar analysis is conducted for the duration of the commodity price busts. The results presented in Table 5 follow the same structure as in Table 3 and also provide clear evidence of increasing positive duration dependence. Therefore, commodity prices busts are also characterized by an accelerated propensity to end as they grow older.

Regarding truncation and frailty, the results are not sensitive either to the truncation (Column 2) of the model to the minimum observable duration of the busts (i.e. 5 quarters) or to the unobserved heterogeneity (Column 3). In this case, the LR-test presented at the bottom of the table indicates that frailty is not a concern. There is strong evidence that commodity price busts have been shorter in the nineties and the 2000s.

The model is, then, extended with time-invariant control variables, i.e. Event, Prev, and DurPrev. Here, Prev is also equal to one if the previous phase was a normal 
time spell, and zero otherwise. None of the dynamics from previous events has proven to be relevant. ${ }^{25}$

\section{[Insert Table 5 here]}

The results from the extended model with the economic and environmental variables presented in Table 6 confirm the presence of increasing duration dependence and the importance of the economic factors. Specifically, large and sudden commodity price downturns tend to be associated with a worsening in world economic activity, unfavourable climate changes and military conflicts (Frankel and Rose, 2010; Auffhammer and Schlenker, 2014; Raleigh et al., 2015; Carleton and Hsiang, 2016).

Thus, commodity price busts are shorter when global growth, interest rates, liquidity and violence are higher, but their length increases with a rise in inflation and the rainfall. A better economic juncture favours the transition to periods of normal growth in commodity prices or even to booms. More rain is linked with improved conditions for the production of agricultural commodities, leading to lower prices that remain below their normal values for longer periods of time. In this context, such event can be thought as capturing a positive development in the supply side of commodity markets.

The empirical findings also show that the duration of commodity price busts has decreased over time/events and that the longer the previous phase, the higher the propensity for a period of commodity price bust ending (i.e., the shorter it will be).

No significant differences are found either between high- and low-income countries or between OECD and non-OECD countries (Columns 3 and 4). However, when the sample is split between non-OECD and OECD countries (Columns 5 and 6, respectively), the duration of the previous event - in particular, if it is a normal time spell - the U.S. real GDP growth and uncertainty matter more for OECD than for nonOECD members. Inflation matters only for non-OECD countries, while InterestRate, Liquidity, Violence and Rainfall remain relevant for both groups. Even though duration dependence parameter estimates are higher for non-OECD countries, when we test for the difference (Columns 7 and 8), the coefficient on $\Delta p$ is not significant.

[Insert Table 6 here]

\footnotetext{
${ }^{25}$ However, in Table 6, we will show that with the inclusion of additional regressors, the importance of Event and DurPrev for the duration of commodity price busts is unveiled.
} 


\subsection{Normal times}

The results for the duration of normal time spells are shown in Table 7. We start with a basic Weibull estimation, but do not find any evidence of duration dependence. As the minimum observed duration for the normal times is one quarter, there is no need of truncating the model. Therefore, in Column 2, we report the results accounting for the unobserved heterogeneity, which confirm its presence. At the same time, we unveil the presence of a decreasing positive duration dependence. In fact, not controlling for frailty, when it is present, (or, instead, omitting relevant observed factors/covariates) will bias the duration dependence parameter downwards (Jenkins, 1995).

To circumvent the frailty problem, we add regional and decade dummies (Column 3), and time invariant controllers (Column 4). As some variables may explain the duration of the commodity price phases, we sequentially add them to the model to circumvent the problem of omission of relevant variables/controllers. ${ }^{26}$ While regional individual effects remain highly significant, time dummies do not. Moreover, the magnitude and even the significance of the duration dependence parameter are undermined. This may mean that these effects are not strong enough to account for the model's heterogeneity. In fact, when we add the controllers for the dynamics of previous phases and the order of these events (Column 4), the duration dependence coefficient approaches the one obtained with only the frailty factor in the model. Despite confirming the presence of decreasing positive duration dependence, the results also show that normal times in commodity prices have become shorter over time; and they are shorter when preceded by a long boom.

\section{[Insert Table 7 here]}

However, when we account for economic and environmental factors (Table 8), only the coefficient associated with the trend variable Event remains statistically significant. Most of the effects on the length of normal times are driven by the economic conditions. Normal times are shorter when inflation rate increases, but they are lengthened by interest rate rises, and with more liquidity in the economy, uncertainty and state-based violence. Temperature and Rainfall do not play any significant role. Similarly, no significant differences are found between high- and lowincome countries and between the OECD and non-OECD members (Columns 3 and 4).

\footnotetext{
${ }^{26}$ Even though we find frailty effects, most of the heterogeneity can be accounted for by including observable factors in the model. Hence, we can rule out the frailty factor from the specification. Actually, it does not render well with the inclusion of additional covariates (or observable factors), as they conflict with each other undermining the convergence of the maximum likelihood estimation.
} 
With the inclusion of these additional explanatory variables, the evidence of a positive duration dependence is reinforced. We even have evidence that the likelihood of these events ending - at moment $t$ given they lasted until that moment - increases at an increasing rate over their duration. However, the duration dependence parameter is substantially lower when compared with the one estimated for booms and busts.

Surprisingly, even though the coefficient on the OECD dummy is not relevant, but when the sample is split between non-OECD and OECD countries (see Columns 5 and 6, respectively), we find significantly different duration dependence dynamics. There is an increasing positive duration dependence for the non-OECD countries and the constant duration dependence for the OECD countries. Hence, duration dependence explains shorter normal time spells in developing or emerging countries compared to developed markets.

To assess whether this difference is statistically significant or not, the model is adjusted as before (Columns 7 and 8). The results clearly show that the duration dependence parameter is significantly lower in the OECD countries, which implies longer normal times in this group. More specifically, it points out to constant dynamics in the industrialised countries vis-à-vis an increasing one in the developing/emerging countries.

[Insert Table 8 here]

\subsection{The role of energy prices}

The length of commodity price phases may also be influenced by the cost of energy. Indeed, the higher the energy costs, the more expensive the extraction, production and transport of commodities will be. Moreover, there might be spillovers from oil (energy) to non-oil (non-energy) commodity prices (Avalos, 2014; Salah Uddin et al., 2018a, 2019). This, in turn, may lead to a boom in commodity prices.

As a result, in this Section, we add oil and energy price indices - one at a time to the baseline model specifications. OilPrice corresponds to the crude oil (petroleum) price index (base year $2005=100$ ) and is computed as the simple average of three spot prices: Dubai Fateh, U.K. Brent and West Texas Intermediate. This variable is considered first in our analysis given the longer sample data availability and the fact that oil prices tend to drive overall energy prices. Next, we consider EnergyPrice, which corresponds to the fuel energy index (base year $2005=100$ ). It includes crude oil (petroleum), natural gas, and coal price indices. Despite being a more precise proxy for 
energy prices, this time-series is shorter than OilPrice, which implies that some observations/spells are lost in the estimation. As for other economic and environmental controllers, we consider their averages over each spell.

The results are presented in Table 9 and show that when oil price indices increase by one percentage point, the hazard of a boom ending falls by around $7.8 \%$ (Column 1). This means that commodity price booms are more likely to survive or last longer, the higher oil prices are. The evidence is less clear-cut for energy prices (Column 2). On the contrary, increases in oil/energy prices hasten the end of bust episodes, thus, shortening them (see Columns 3 and 4). This result is consistent with the previous one, as increases in energy prices tend to drive increases in overall commodity prices and, thus, booms can last longer, the more persistent the rise in energy prices is.

In sum, oil prices play an important role in shaping the commodity price cycle, in particular, by making busts shorter and booms longer when they rise worldwide. Indeed, our results highlight the relevance of spillover effects from (oil) energy prices to commodity prices and the need of looking at the length of their cycle phases to better understand their dynamics.

\section{[Insert Table 9 here]}

\subsection{Sensitivity analysis}

In this Section, we assess the robustness of the main findings to: (i) a different uncertainty measure; (ii) a broader set of control variables; and (iii) alternative identification schemes for commodity price cycle phases.

In this context, we start by replacing the U.S. economic policy uncertainty (EPU) index (Uncertainty) by Baker et al. (2016) with the global geopolitical risk index (GeoPolRisk) by Caldara and Iacoviello (2018) in our baseline models. Data are sourced from: https://www.policyuncertainty.com/gpr.html.

The geopolitical risk index counts the occurrence of words related to geopolitical tensions in 11 leading international newspapers. It covers words associated with: (i) geopolitical risk and military-related tensions; (ii) nuclear tensions; (iii) war threats; (iv) terrorist threats; (v) actual adverse geopolitical events (as opposed to risks); and (vi) the beginning of a war or terrorist acts. Then, it is normalised to average a value of 100 in the period 2000-2009. 
The results are reported in Column 1 of Tables 10-12, which presents the findings associated with our models for commodity price booms, busts and normal times, respectively.

As can be seen, the empirical findings are qualitatively similar to those associated with our baseline models (see Column 1 of Tables 4, 6 and 8). Yet, despite having the same sign of the coefficients associated with economic policy uncertainty (Uncertainty), geopolitical risk (GeoPolRisk) does not significantly affect the duration of any of the three commodity price cycle phases considered in this study.

Moreover, as noted by Reinhart et al. (2016), capital flow cycles are a relevant driver of the commodity price cycle. Similarly, the stock market or credit cycle is a relevant determinant of commodity boom-bust phases (Ftiti et al., 2016). Consequently, we account for the capital flow cycle and the credit cycle in our estimations. Specifically, we add (one at time): (i) global capital flow boom phases (CapFlowBoom) to the model for commodity price booms and global capital flow bust phases (CapFlowBust) to the models for commodity price busts and normal times; and (ii) and credit boom phases (CredBoom) to the model for commodity price booms and credit bust phases (CredBust) to the models for commodity price busts and normal times.

Global capital flow boom-bust phases are obtained from Reinhart et al. (2016), who apply the mechanical scheme for dating turning points in business cycles by Harding and Pagan (2002) to capital flow series. The authors use data on capital flows to capital-importing countries over the past 200 years based on information about gross capital exports (i.e. international sovereign bond issuances) and net capital inflows (namely, current account and changes in official reserves). Capital boom phases (CapFlowBoom) are a dummy variable that takes the value of one in the case of a capital flow boom (or "bonanza") episode, and zero, otherwise. Similarly, capital flow bust phases (CapFlowBust) are a dummy variable that takes the value of one in the case of a capital flow bust episode, and zero, otherwise.

As for the credit cycle, we draw on the work of Avdjiev et al. (2017), who identify credit booms, credit busts and "normal times" using the framework put forward by Agnello et al. (2015, 2017). Thus, Avdjiev et al. (2017) smooth quarterly real credit growth using a moving average and the (cumulative) real credit growth in a upturn (downturn) is required to exceed (fall below) a minimum (maximum) threshold before it can be labelled as a credit boom (bust). As our paper focuses on the global determinants of the duration of commodity price cycle phases, we use the phases of the credit cycle in 
the U.S. - as identified by Avdjiev et al. (2017) - as a proxy for the global credit cycle. Thus, CredBoom (CredBust) is a dummy variable that takes the value of one in the case of a credit boom (bust), and zero, otherwise.

The results are reported in Columns 2-3 of Tables 10-12 for commodity price booms, busts and normal times, respectively. The evidence clearly shows that when we account for capital flow and credit boom-bust episodes, the findings associated with our baseline models remain qualitatively and quantitatively unchanged. Moreover, while credit booms have a statistically significant effect on the length of commodity price booms and credit flow busts significantly impact the duration of commodity price busts, none of the additional control variables seem to affect the length of normal time spells.

Finally, we assess the robustness of our main results through the lens of different identification schemes. Specifically, we set thresholds for commodity price booms (busts) equal to the median value of cumulative real commodity export price growth during upturns (downturns). These amount to $7 \%$ for booms and $-21 \%$ for busts. Alternatively, we identify commodity price booms (busts) as periods of consecutive upturns (downturns) in the real country-specific commodity export index, such that the cumulative real commodity export price growth exceeds (falls below) the top (bottom) quartile of the distribution. These are $29 \%$ for booms and $-35 \%$ for busts.

We find that there is some loss of statistical significance for variables like InterestRate and Uncertainty in the case of commodity price booms, RGDPgr and Violence for commodity price busts, and Event, Inflation, InterestRate, Liquidity and Uncertainty in the case of normal times. Yet, the key results are qualitatively and quantitatively very similar to those associated with our baseline models where thresholds for commodity price booms (busts) are set in accordance with the average cumulative real commodity export price growth during upturns (downturns).

[Insert Table 10 here]

[Insert Table 11 here]

[Insert Table 12 here]

\section{Conclusions}

In this article, we use quarterly data for a group of 33 economies (including commodity exporters from both industrialised countries and emerging markets) over the period 1980Q1-2015Q4 and a continuous-time version of a Weibull duration model to investigate how global factors shape the length of commodity price cycle phases. 
The results support the existence of a positive duration dependence in the boombust cycle phases. Thus, as time goes by, imbalances in commodity markets - reflected in large deviations of prices from their fundamentals - tend to be corrected in a return to normal time spells, which means that the probability of commodity price booms' ending at time $t$, given that they lasted until that moment, rises over time at an increasing rate. However, the time dynamics are not the only explanation for the length of such commodity price cycle phases as global economic and environmental conditions also matter to explain their dynamics. As expected, these factors display opposite effects on the duration of commodity price booms and busts.

Another valuable finding of this work is that oil/energy prices crucially shape commodity price cycle phases, confirming the evidence in previous studies of important spillovers from energy prices to other commodity prices (Avalos, 2014; Salah Uddin et al., 2018a, 2019). Specifically, we find that increases in oil prices make commodity price busts shorter and booms longer. This can be explained as the result of two effects: (i) a direct effect on the overall commodity price index, as one of its components; and (ii) an indirect effect - and, perhaps, more powerful - on the costs of production and/or extraction of other commodities, consequently driving their prices.

Our key results remain qualitatively and quantitatively unchanged when we consider: (i) a different uncertainty measure; (ii) a broader set of control variables; and (iii) alternative identification schemes for commodity price cycle phases.

From a policy point of view, our results are relevant for analysing the timing and the duration of commodity price cycle phases. They can be informative for the design of investment strategies and the implementation of stabilisation policies given the influence of commodity prices on consumer prices and the business cycle. An assessment of the drivers of commodity prices together with an accurate analysis of their cycles can ultimately support investors in commodity markets in their asset portfolio decisions. It can also help policymakers by preventing the disruptive welfare effects of sharp commodity price shifts and by increasing the efficacy of countercyclical stabilization policies.

Global interest rate hikes are associated with shorter commodity price booms and longer busts. Consequently, we find not only support for a negative impact of monetary policy or global liquidity tightening on commodity prices (Ratti and Vespignani, 2015, 2016; Avalos and Lombardi, 2015), but also show that it can affect the length of commodity price cycle phases. Hence, monetary policy can counter-act the 
destabilising effects of commodity price boom-bust phases. Moreover, global liquidity and growth-enhancing policies are not without unintended consequences (Belke et al., 2010, 2013, 2014; Beckmann et al., 2014), as eased global liquidity conditions and strengthened global activity are associated with longer commodity price booms and shorter busts. Thus, a careful and integrated policy setup is crucial to avoid the emergence of price misalignments, such as bubbles, in commodity markets.

Finally, as our study shows, global factors are key drivers of the length of commodity price cycle phases. This implies that not only commodity prices but also economies around the globe are exposed to a common set of factors. The odds are that an important fraction of the variation that we observe among the prices of different commodity classes and the real economic activity across different countries translates into international co-movement and synchronisation. We leave this issue for future research.

\section{References}

Adalid, R., and C. Detken, 2007. Liquidity shocks and asset price boom/bust cycles. ECB Working Paper no. 732.

Agnello, L., Castro, V., Hammoudeh, S., and R.M. Sousa, 2017. Spillovers from the oil sector to the housing market cycle. Energy Economics, 61, 209-220.

Agnello, L., Castro, V., and R.M. Sousa, 2013. What determines the duration of a fiscal consolidation program? Journal of International Money and Finance, 37, 113-134.

Agnello, L., Castro, V., and R.M. Sousa, 2015. Booms, busts and normal times in the housing market. Journal of Business \& Economic Statistics, 33(1), 25-45.

Agnello, L., Castro, V., and R.M. Sousa, 2018. The legacy and the tyranny of time: Exit and re-entry of sovereigns to international capital markets. Journal of Money Credit and Banking, 50(8), 1969-1994.

Agnello, L., Castro, V., and R.M. Sousa, 2019. On the duration of sovereign ratings cycle phases. Journal of Economic Behavior and Organization, forthcoming. Available at: https://doi.org/10.1016/j.jebo.2019.01.016.

Agnello, L., Schuknecht, L., 2011. Booms and busts in housing markets: Determinants and implications. Journal of Housing Economics, 20(3), 171-190.

Akram Q.F., 2009. Commodity prices, interest rates and the dollar. Energy Economics, 31, 838-851. 
Alberola, E., and R. Sousa, 2017. Assessing fiscal policy through the lens of the financial and the commodity price cycles. BIS Working Paper no. 638.

Allison, P., 2014. Quantitative Applications in the Social Sciences: Event history and survival analysis. Thousand Oaks, CA: SAGE Publications.

Arezki, R., and O. Blanchard, 2014. Seven questions about the recent oil price slump. IMFBlog - Insights \& Analysis on Economics \& Finance, 22 December.

Arezki, R., and M. Brückner, 2012. Rainfall, financial development, and remittances: Evidence from Sub-Saharan Africa", Journal of International Economics, 87(2), 377-385.

Arezki, R., Hadri, K., Loungani, P., and Y. Rao, 2014a. Testing the Prebisch-Singer Hypothesis Since 1650: Evidence from panel techniques that allow for multiple breaks. Journal of International Money and Finance, 42, 208-223.

Arezki, R., Loungani, P., van der Ploeg, R., and A.J. Venables, 2014b. Understanding international commodity price fluctuations. Journal of International Money and Finance, $42,1-8$.

Auffhammer, M., and W. Schlenker, 2014. Empirical studies on agricultural impacts and adaptation. Energy Economics, 46, 555-561.

Avalos, F., 2014. Do oil prices drive food prices? The tale of a structural break. Journal of International Money and Finance, 42, 253-271.

Avalos, F., and M.J. Lombardi, 2015. The biofuel connection: impact of US regulation on oil and food prices. BIS Working Paper no. 487.

Avdjiev, S., Binder, S., and R. Sousa, 2017. External debt composition and domestic credit cycles. BIS Working Paper no. 627.

Baker, S.R., Bloom, N., and S.J. Davis, 2016. Measuring economic policy uncertainty. The Quarterly Journal of Economics, 131(4), 1593-1636.

Bazzi, S., and C. Blattman, 2014. Economic shocks and conflict: Evidence from commodity prices. American Economic Journal: Macroeconomics, 6, 1-38.

Beckmann, J., Belke, A., and R. Czudaj, 2014. Does global liquidity drive commodity prices? Journal of Banking \& Finance, 48(C), pages 224-234.

Belke, A.H., Bordon, I.G., and U. Volz, 2013. Effects of global liquidity on commodity and food prices. World Development, 44(C), 31-43.

Belke, A.H., Bordon, I.G., and T.W. Hendricks, 2014. Monetary policy, global liquidity and commodity price dynamics. North American Journal of Economics and Finance, 28, 1-16. 
Belke, A.H., Orth, W., and R. Setzer, 2010. Liquidity and the dynamic pattern of asset price adjustment: a global view. Journal of Banking and Finance, 34, 1933-1945.

Bordo, M.C., and O. Jeanne, 2002. Monetary policy and asset prices: Does 'benign neglect' make sense? International Finance, 5(2), 139-164.

Borio, C., and P. Lowe, 2002. Asset prices, financial and monetary stability: Exploring the nexus. BIS Working Paper no. 114.

Burns, A.F., and W.C. Mitchell, 1946. Measuring business cycles. NBER Studies in Business Cycles, vol. 2. National Bureau of Economic Research: New York, USA.

Büyükşahin, B., and J.H. Harris, 2011. Do speculators drive crude oil futures prices? The Energy Journal, 32(2), 167-202.

Büyükşahin, B., Mo, K., and K. Zmitrowicz, 2016. Commodity price supercycles: What are they and what lies ahead? Bank of Canada Review, Autumn, 35-46.

Caldara, D., and M. Iacoviello, 2018. Measuring geopolitical risk. Board of Governors of the Federal Reserve System, International Finance Discussion Paper no. 1222.

Carleton, T.A., and S.M. Hsiang, 2016. Social and economic impacts of climate. Science, 353, 1-15.

Cashin, P., McDermott, C.J., and A. Scott, 2002. Booms and slumps in world commodity prices. Journal of Development Economics, 69, 277-296.

Castro, V., 2010. The duration of economic expansions and recessions: More than duration dependence. Journal of Macroeconomics, 32, 347-365.

Castro, V., 2013. The duration of business cycle expansions and contractions: Are there change-points in duration dependence? Empirical Economics, 44, 511-544.

Claessens, S., Kose, M.A., and M.E. Terrones, 2011. Financial cycles: What? How? When? IMF Working Paper no. 76.

Deaton, A., 1999. Commodity prices and growth in Africa. Journal of Economic Perspectives, 13, 23-40.

Deaton, A., and G. Laroque, 1992. On the behaviour of commodity prices. Review of Economic Studies, 59, 1-25.

Detken, C., and F. Smets, 2004. Asset prices booms and monetary policy. ECB Working Paper no.364.

Dube, O., and J.F. Vargas, 2013. Commodity price shocks and civil conflict: Evidence from Colombia. Review of Economic Studies, 80, 1384-1421. 
El-Gamal, M.A., and A.M. Jaffe, 2018. The coupled cycles of geopolitics and oil prices. Economics of Energy and Environmental Policy, 7(2). Available at: https://doi.org/ 10.5547/2160-5890.7.2.melg.

Erdem, F.P., and I. Ünalmıs, 2016. Revisiting super-cycles in commodity prices. Central Bank Review, 16(4), 137-142.

Erten, B., and J.A. Ocampo, 2013. Super cycles of commodity prices since the midnineteenth century. World Development, 44, 14-30.

Frankel, J.A., 2006. The effect of monetary policy on real commodity prices. In: Campbell, J., Ed., Asset Prices and Monetary Policy. University of Chicago Press: Chicago, USA.

Frankel, J.A., and A.K. Rose, 2010. Determinants of agricultural and mineral commodity prices. In: Fry, R., Jones, C., and C. Kent, eds., Inflation in an era of relative price shocks, Reserve Bank of Australia: Sydney, Australia, 9-51.

Ftiti, Z., Kablan, S., and K. Guesmi, 2016. What can we learn about commodity and credit cycles? Evidence from African commodity-exporting countries. Energy Economics, 60, 313-324.

Gilbert C.L., 2010. How to understand high food prices. Journal of Agricultural Economics, 61(2), 398-425.

Grilli, E., and M.-C. Yang, 1988. Primary commodity prices, manufactured goods prices and the terms of trade in developing countries. World Bank Economic Review, $2,1-47$.

Gutierrez, R., Carter, S., and D. Drukker, 2001. On boundary-value likelihood-ratio tests. Stata Technical Bulletin, 60, 15-18. Reprinted in: Stata Technical Bulletin Reprints, 8, 233-236.

Hamilton, J., 1989. A new approach to the economic analysis of non-stationary time series and the business cycle. Econometrica, 57, 357-384.

Hammoudeh, S., Nguyen, D.K., and R.M. Sousa, 2015. US monetary policy and commodity sector prices. Journal of International Money and Finance, 57, 61-85.

Hammoudeh, S., and Y. Yuan, 2008. Metal volatility in presence of oil and interest rate shocks. Energy Economics, 30, 606-620.

Harding, D., and A. Pagan, 2002. Dissecting the cycle: A methodological investigation. Journal of Monetary Economics, 49(2), 365-381. 
Hess, W., and M. Persson, 2010. The duration of trade revisited: Continuous-time vs. discrete-time hazards. Research Institute of Industrial Economics, IFN Working Paper no. 829.

Humphreys, D., 2010. The great metals boom: A retrospective. Resources Policy, 35, 113.

Jenkins, S., 1995. Easy estimation methods for discrete-time duration models. Oxford Bulletin of Economics and Statistics, 57, 129-138.

Jenkins, S., 2005. Survival Analysis. University of Essex, mimeo. Available at: https://www.iser.essex.ac.uk/files/teaching/stephenj/ec968/pdfs/ec9681notesv6.pdf.

Kiefer, N., 1988. Economic duration data and hazard functions. Journal of Economic Literature, 26, 646-679.

Kohlscheen, E., Avalos, F., and A. Schrimpf, 2017. When the walk is not random: commodity prices and exchange rates. International Journal of Central Banking, 13(2), 121-158.

Labys, W.C., Achouch, A., and M. Terraza, 1999. Metal prices and the business cycle. Resources Policy, 25(4), 229-238.

Lancaster, T., 1990. The Econometric Analysis of Transition Data, Cambridge: Cambridge University Press.

Loungani, P., 1986. Oil price shocks and the dispersion hypothesis. Review of Economics and Statistics, 68(3), 536-539.

Loungani, P., 2009. The elusive quest for energy independence. International Finance, 12(2), 291-299.

Miguel, E., Satyanath, S., and E. Sergenti, 2004. Economic shocks and civil conflict: An Instrumental Variables approach. Journal of Political Economy, 112(4), 725-753.

Munasinghe, L., Jun, T., and D.H. Rind, 2012. Climate change: A new metric to measure changes in the frequency of extreme temperatures using record data. Climatic Change, $113,1001-1024$

Pindyck, R.S., and J.J. Rotemberg, 1990. The excess co-movement of commodity prices. Economic Journal, 100, 1173-1187.

Prokopczuk, M., and C. Wese Simen, 2014. The importance of the volatility risk premium for volatility forecasting. Journal of Banking and Finance, 40, 303-320.

Prokopczuk, M., Stancu, A., and L. Symeonidis, 2019. The economic drivers of commodity market volatility. Journal of International Money and Finance, article 102063, 1-23. 
Prokopczuk, M., Wese Simen, C., and L. Symeonidis, 2017. Variance risk in commodity markets. Journal of Banking and Finance, 81, 136-149.

Radetzki, M., 2006. The anatomy of three commodity booms. Resources Policy, 36, 56-64.

Raleigh, C., Choi, H.J., and D. Kniveton, 2015. The devil is in the details: An investigation of the relationships between conflict, food price and climate across Africa. Global Environment Change, 32, 187-199.

Ratti, R.A., J.L. Vespignani, 2015. Commodity prices and BRIC and G3 liquidity: a SFAVEC approach. Journal of Banking and Finance, 18-33.

Ratti, R., and J.L. Vespignani, 2016. Oil prices and global factor macroeconomic variables. Energy Economics, 59, 198-212.

Reinhart, C.M., Reinhart, V., and C. Trebesch, 2016. Global cycles: Capital flows, commodities, and sovereign defaults, 1815-2015. American Economic Review, 106(5), 574-580.

Rodríguez, G. , 2010. Parametric survival models. Princeton University, Working Paper.

Salah Uddin, G., Areola Hernandez, J., Jawad Hussain Shahzad, S., and A. Hedström, 2018a. Multivariate dependence and spillover effects across energy commodities and diversification potentials of carbon assets. Energy Economics, 71, 35-46.

Salah Uddin, G., Bekiros, S., and A. Ahmed, 2018b. The nexus between geopolitical uncertainty and crude oil markets: An entropy-based wavelet analysis. Physica A, 495, 3039.

Salah Uddin, G., Lutfur Rahman, M., Jawad Hussain Shahzad, S., and M. Ur Rehman, 2018c. Supply and demand driven oil price changes and their non-linear impact on precious metal returns: A Markov regime switching approach. Energy Economics, 73, 108-121.

Salah Uddin, G., Lutfur Rahman, M., Hedström, A., and A. Ahmed, 2019. Crossquantilogram-based correlation and dependence between renewable energy stock and other asset classes. Energy Economics, 80, 743-759.

Sensoy, A., 2013. Dynamic relationship between precious metals. Resources Policy, 38(4), 504-511.

Sensoy, A., and E. Hacihasanoglu, 2014. Time-varying long-range dependence in energy futures markets. Energy Economics, 46, 318-327.

Sensoy, A., Ozturk, K., and E. Hacihasanoglu, 2014. Constructing a financial fragility index for emerging countries. Finance Research Letters, 11, 410-419.

Sensoy, A., Hacihasanoglu, E., and D.K. Nguyen, 2015. Dynamic convergence of commodity futures: Not all types of commodities are alike. Resources Policy, 44, 150-160. 
Sichel, D., 1991. Business cycle duration dependence: A parametric approach. Review of Economics and Statistics, 73, 254-260.

Slade, M., 1982. Trends in natural-resource commodity prices: An analysis of the time domain. Journal of Environmental Economics and Management, 9(2), 122-137.

Spatafora N., and I. Tytell, 2009. Commodity terms of trade: The history of booms and busts. IMF Working Paper no. 205.

Turner, P., 2017. Did central banks cause the last financial crisis? Will they cause the next? LSE Financial Markets Group (FMG) Paper Series, Special Paper no. 249.

Turner, P., 2018. The macroeconomics of macroprudential policies. In: Mizen, P., Rubio, M., and P. Turner, eds. Macroprudential policy and practice. Chapter 1, 1945. Cambridge University Press: Cambridge, UK. 
List of Tables

Table 1. Description of variables.

\begin{tabular}{|c|c|c|}
\hline Variable & Description & Source \\
\hline Dur & Duration of booms, busts or normal times, in quarters. & UN Comtrade: https://comtrade.un.org/; authors' calculations. \\
\hline Event & $\begin{array}{l}\text { Variable that measures the order of the event (boom, bust, normal time) in time and for each country. For example, it indicates if the } \\
\text { respective event spell was the first, second, third,etc. to be observed in the period under analysis. }\end{array}$ & UN Comtrade: https://comtrade.un.org/; authors' calculations. \\
\hline Prev & $\begin{array}{l}\text { Dummy variable that identifies the previous event }(=1 \text { if normal times precede booms or busts; or }=1 \text { if a boom precedes normal times; } 0 \text {, } \\
\text { otherwise. }\end{array}$ & UN Comtrade: https://comtrade.un.org/; authors' calculations. \\
\hline DurPrev & Duration of the previous event & UN Comtrade: https://comtrade.un.org/; authors' calculations. \\
\hline RGDPgr & U.S. Gross Domestic Product growth rate & $\begin{array}{l}\text { IFS, IMF: https://data.imf.org/?sk=4C514D48-B6BA-49ED-8AB9- } \\
\text { 52B0C1A0179B }\end{array}$ \\
\hline Inflation & U.S. inflation rate & BIS: https://www.bis.org/statistics/cp.htm?m=6\%7C382\%7C678 \\
\hline InterestRate & U.S. Federal Reserve policy rate & BIS: https://www.bis.org/statistics/cbpol.htm?m=6\%7C382\%7C679 \\
\hline Liquidity & $\begin{array}{l}\text { Global liquidity (as percentage of GDP). It is proxied by banks' international claims, i.e. banks' cross-border financial assets (including loans, } \\
\text { holdings of debt and equity securities, derivatives and other financial instruments) denominated in all currencies plus their local claims } \\
\text { denominated in foreign currencies. }\end{array}$ & BIS: https://www.bis.org/statistics/gli.htm?m=6\%7C333\%7C690 \\
\hline Uncertainty & U.S. Economic policy uncertainty index & http://www.policyuncertainty.com; Baker et al. (2016) \\
\hline Violence & $\begin{array}{l}\text { Number of military conflicts. It corresponds to the sum of state-based, non-state based and one-sided violence events. As noted by Dube and } \\
\text { Vargas (2013) and Bazzi and Blattman (2014), this enables tracking the intensity of conflicts at any given moment in time. Data are provided } \\
\text { by the Department of Peace and Conflict Research of the Uppsala Conflict Data Program (UCDP). In addition to the standard 1,000-death } \\
\text { threshold, this unique dataset records all armed conflicts defined as "contested incompatibilities which concern government and/or territory } \\
\text { where the use of armed force between two parties, of which at least one is the government of a state, results in at least } 25 \text { battle deaths per } \\
\text { year". Thus, it allows one to include more small conflicts in the analysis (Miguel } \text { et al., 2004). }\end{array}$ & UCDP: https://ucdp.uu.se/ \\
\hline $\begin{array}{l}\text { Temperature and } \\
\text { Rainfall }\end{array}$ & $\begin{array}{l}\text { World's average temperature and rainfall. The world's average temperature and rainfall are computed as simple averages across } 245 \text { countries } \\
\text { for which data from the World Bank's Climate Change Knowledge Portal (CCKP) are available. Compared to other control variables, these } \\
\text { determinants are more likely to capture "purely" supply-side effects on commodity markets. Munasinghe et al. (2012) highlight the } \\
\text { importance of the level of temperature and precipitations and climate changes as determinants of agricultural production and prices. Arezki } \\
\text { and Brückner (2012) also use rainfall as a proxy for exogenous, transitory income shocks, and find that it has a significant effect on } \\
\text { remittances in a panel of } 41 \text { Sub-Saharan African countries over the period 1970-2007. }\end{array}$ & $\begin{array}{l}\text { CCKP: https://datacatalog.worldbank.org/dataset/climate-change- } \\
\text { knowledge-portal-historical-data }\end{array}$ \\
\hline HighIncome & Dummy equal to 1 for high-income countries; 0 , otherwise. & WDI: http://wdi.worldbank.org/ \\
\hline OilPrice & $\begin{array}{l}\text { Crude Oil (petroleum), Price index, } 2005=100 \text {; simple average of three spot prices: Dubai Fateh, U.K. Brent and West Texas Intermediate; } \\
\text { period average. }\end{array}$ & $\begin{array}{l}\text { IFS, IMF: (https://data.imf.org/?sk=4C514D48-B6BA-49ED-8AB9- } \\
\text { 52B0C1A0179B) }\end{array}$ \\
\hline EnergyPrice & Fuel (Energy) Index, 2005 = 100, includes Crude oil (petroleum), Natural Gas, Coal Price Indices; period average. & IMF: https://www.imf.org/en/Research/commodity-prices \\
\hline $\begin{array}{l}\text { Regional dummies }(O E C D \text {, } \\
\text { AFR, EAP, ECA, LAC, } \\
M E N A, N A M, S A S)\end{array}$ & $\begin{array}{l}\text { Dummy variable equal to } 1 \text { for either OECD countries (OECD), Africa }(A F R) \text {, East Asia and Pacific }(E A P) \text {, Europe and Central Asia }(E C A) \text {, } \\
\text { Latin America and the Caribbean }(L A C) \text {, Middle East and North Africa }(M E N A) \text {, North America }(N A M) \text { or South Asia (SAS), respectively, } \\
\text { and 0, otherwise. }\end{array}$ & WDI: http://wdi.worldbank.org/ \\
\hline GeoPolRisk & Global geopolitical risk index. & http://www.policyuncertainty.com; Caldara and Iacoviello (2018) \\
\hline CapFlowBoom (CapFlowBust) & Dummy equal to 1 for capital flow boom (bust) episode; 0 , otherwise. & Reinhart et al. (2016) \\
\hline CredBoom (CredBust) & Dummy equal to 1 for credit boom (bust) episode; 0 , otherwise. & Avdjiev et al. (2017) \\
\hline
\end{tabular}


Table 2. Descriptive statistics.

\begin{tabular}{|c|c|c|c|c|c|c|c|c|c|c|c|c|c|c|c|}
\hline & \multicolumn{5}{|c|}{ Booms } & \multicolumn{5}{|c|}{ Busts } & \multicolumn{5}{|c|}{ Normal times } \\
\hline & Spells & Mean & Std. Dev. & Min. & Max. & Spells & Mean & Std. Dev. & Min. & Max. & Spells & Mean & Std. Dev. & Min. & Max. \\
\hline \multicolumn{16}{|l|}{ Dur } \\
\hline All sample & 97 & 11.7 & 5.8 & 4 & 25 & 136 & 13.0 & 5.5 & 5 & 31 & 169 & 11.0 & 11.8 & 1 & 70 \\
\hline$O E C D$ & 47 & 12.4 & 6.2 & 4 & 25 & 70 & 12.7 & 5.6 & 5 & 31 & 83 & 11.8 & 13.4 & 1 & 70 \\
\hline Non-OECD & 50 & 11.1 & 5.3 & 5 & 24 & 66 & 13.3 & 5.4 & 5 & 29 & 86 & 10.1 & 9.9 & 1 & 56 \\
\hline Event & 97 & 2.1 & 0.9 & 1 & 4 & 136 & 2.7 & 1.4 & 1 & 7 & 169 & 3.1 & 1.6 & 1 & 7 \\
\hline Prev & 97 & 0.7 & 0.5 & 0 & 1 & 136 & 0.7 & 0.5 & 0 & 1 & 136 & 0.4 & 0.5 & 0 & 1 \\
\hline DurPrev & 97 & 9.9 & 10.3 & 1 & 70 & 136 & 10.8 & 10.6 & 1 & 56 & 136 & 13.4 & 8.5 & 1 & 70 \\
\hline RGDPgr & 97 & 2.4 & 1.1 & 1.2 & 7.4 & 136 & 2.3 & 2.0 & -1.9 & 6.0 & 169 & 2.2 & 1.7 & -1.9 & 4.6 \\
\hline Inflation & 97 & 2.2 & 0.9 & 0.8 & 5.1 & 136 & 3.8 & 2.5 & 1.1 & 11.4 & 169 & 4.7 & 3.4 & 1.7 & 12.7 \\
\hline InterestRate & 97 & 2.6 & 2.4 & 0.1 & 10.8 & 136 & 5.6 & 4.7 & 0.1 & 15.6 & 169 & 6.9 & 5.6 & 0.1 & 19.9 \\
\hline Liquidity & 97 & 48.2 & 9.4 & 19.2 & 63.3 & 136 & 34.2 & 12.0 & 15.9 & 56.8 & 148 & 36.1 & 11.9 & 14.6 & 63.3 \\
\hline Uncertainty & 95 & 111.4 & 24.2 & 78.5 & 145.2 & 127 & 115.2 & 22.1 & 84.8 & 153.1 & 136 & 112.9 & 28.8 & 49.3 & 171.5 \\
\hline Violence & 97 & 35.1 & 3.6 & 32.0 & 45.8 & 136 & 41.2 & 2.9 & 36.7 & 49.1 & 169 & 39.9 & 3.7 & 32.5 & 47.9 \\
\hline Temperature & 97 & 19.5 & 0.3 & 18.5 & 20.0 & 136 & 19.3 & 0.4 & 18.6 & 20.0 & 169 & 19.0 & 1.3 & 15.7 & 22.8 \\
\hline Rainfall & 97 & 114.8 & 3.8 & 102.5 & 120.0 & 136 & 111.1 & 1.8 & 106.3 & 116.0 & 169 & 110.2 & 6.6 & 90.3 & 128.9 \\
\hline OilPrice & 97 & 107.7 & 47.1 & 30.0 & 161.5 & 136 & 82.4 & 56.0 & 25.9 & 170.6 & 169 & 75.0 & 51.3 & 28.8 & 199.3 \\
\hline EnergyPrice & 93 & 109.8 & 44.6 & 32.2 & 159.1 & 88 & 100.6 & 62.0 & 28.2 & 168.7 & 109 & 87.0 & 59.1 & 32.9 & 197.0 \\
\hline Geopolitical risk & 95 & 87.3 & 36.3 & 38.1 & 166.0 & 127 & 72.7 & 18.0 & 45.9 & 116.4 & 136 & 69.1 & 19.4 & 36.2 & 134.5 \\
\hline Capital flow boom & 97 & 0.9 & 0.3 & 0 & 1 & 136 & 0.4 & 0.4 & 0 & 1 & 169 & 0.6 & 0.4 & 0 & 1 \\
\hline Capital flow bust & 97 & 0.1 & 0.3 & 0 & 1 & 136 & 0.5 & 0.4 & 0 & 1 & 169 & 0.4 & 0.4 & 0 & 1 \\
\hline Credit boom & 97 & 0.3 & 0.4 & 0 & 1 & 136 & 0.4 & 0.4 & 0 & 1 & 169 & 0.4 & 0.5 & 0 & 1 \\
\hline Credit bust & 97 & 0.3 & 0.4 & 0 & 1 & 136 & 0.3 & 0.3 & 0 & 1 & 169 & 0.3 & 0.3 & 0 & 1 \\
\hline Credit normal times & 97 & 0.3 & 0.3 & 0 & 1 & 136 & 0.3 & 0.3 & 0 & 1 & 169 & 0.3 & 0.4 & 0 & 1 \\
\hline HighIncome & 97 & 0.5 & 0.5 & 0 & 1 & 136 & 0.5 & 0.5 & 0 & 1 & 169 & 0.5 & 0.5 & 0 & 1 \\
\hline OECD & 97 & 0.5 & 0.5 & 0 & 1 & 136 & 0.5 & 0.5 & 0 & 1 & 169 & 0.5 & 0.5 & 0 & 1 \\
\hline
\end{tabular}

Notes: See Table 1 for sources. S.D. corresponds to the standard deviation; Min. and Max. are the minimum and maximum or each variable. 
Table 3. Duration of commodity price booms $\mathbf{I}$.

\begin{tabular}{|c|c|c|c|c|c|}
\hline & $(1)$ & (2) & (3) & (4) & (5) \\
\hline$\gamma$ & $\begin{array}{c}0.0035 * * * \\
(0.0006)\end{array}$ & $\begin{array}{c}0.0073 * * * \\
(0.0017)\end{array}$ & $\begin{array}{c}0.0003 * * * \\
(0.0001)\end{array}$ & $\begin{array}{c}0.0013 * * \\
(0.0006)\end{array}$ & $\begin{array}{c}0.0011 \\
(0.0009)\end{array}$ \\
\hline$p$ & $\begin{array}{l}2.185^{+, i} \\
(0.078)\end{array}$ & $\begin{array}{l}1.944^{+, \mathrm{c}} \\
(0.095)\end{array}$ & $\begin{array}{l}3.506^{+, \mathrm{i}} \\
(0.109)\end{array}$ & $\begin{array}{l}3.548^{+, \mathrm{i}} \\
(0.250)\end{array}$ & $\begin{array}{l}3.558^{+, i} \\
(0.251)\end{array}$ \\
\hline$\theta$ & & & $\begin{array}{c}2.491 * * * \\
(0.318)\end{array}$ & & \\
\hline EAP & & & & $\begin{array}{c}-1.185^{* * * *} \\
(0.169)\end{array}$ & $\begin{array}{c}-1.112 * * * \\
(0.191)\end{array}$ \\
\hline ECA & & & & $\begin{array}{c}-0.950 * * * \\
(0.177)\end{array}$ & $\begin{array}{c}-0.905 * * * \\
(0.170)\end{array}$ \\
\hline LAC & & & & $\begin{array}{c}-1.190^{* * * *} \\
(0.159)\end{array}$ & $\begin{array}{c}-1.151^{* * *} \\
(0.193)\end{array}$ \\
\hline MENA & & & & $\begin{array}{c}-0.063 * * * \\
(0.009)\end{array}$ & $\begin{array}{c}0.025 \\
(0.177)\end{array}$ \\
\hline NAM & & & & $\begin{array}{c}-1.328 * * * \\
(0.438)\end{array}$ & $\begin{array}{c}-1.275^{* * * *} \\
(0.445)\end{array}$ \\
\hline SAS & & & & $\begin{array}{c}-0.915^{* * *} * \\
(0.159)\end{array}$ & $\begin{array}{c}-0.859 * * * \\
(0.216)\end{array}$ \\
\hline Decade80 & & & & $\begin{array}{l}-0.170 \\
(0.593)\end{array}$ & $\begin{array}{l}-0.059 \\
(0.606)\end{array}$ \\
\hline Decade90 & & & & $\begin{array}{c}0.150 \\
(0.275)\end{array}$ & $\begin{array}{c}0.308 \\
(0.435)\end{array}$ \\
\hline Decade00 & & & & $\begin{array}{c}-2.472 * * * \\
(0.368)\end{array}$ & $\begin{array}{c}-2.306^{* * * *} \\
(0.432)\end{array}$ \\
\hline Event & & & & & $\begin{array}{c}0.044 \\
(0.194)\end{array}$ \\
\hline Prev & & & & & $\begin{array}{l}-0.143 \\
(0.260)\end{array}$ \\
\hline DurPrev & & & & & $\begin{array}{l}-0.006 \\
(0.020)\end{array}$ \\
\hline \#Spells & 97 & 97 & 97 & 97 & 97 \\
\hline LogLik & -69.73 & -293.8 & -62.09 & -33.41 & -33.08 \\
\hline SBIC & 148.6 & 596.8 & 137.9 & 103.4 & 116.5 \\
\hline LR-test & & & 0.000 & & \\
\hline
\end{tabular}

Notes: Heteroscedasticity and serial correlation robust standard errors clustered by country are reported in parenthesis; + indicates that $p$ is significantly higher than 1 using a one-sided test with a $5 \%$ significance level; $d, c$, and $i$ indicate decreasing, constant and increasing positive duration dependence, respectively; ***, **, * - statistical significance at the $1 \%, 5 \%$, and $10 \%$ level, respectively. Column 1 reports results for a basic Weibull specification. Truncation at the minimum value of the observed duration of booms (i.e. four quarters) is used in regressions presented in Column 2. In Column 3, the $p$-value of the LR test for unobserved heterogeneity/frailty assesses whether the estimated variance $(\theta)$ is different from zero or not. Columns 4 and 5 report extensions to the basic model (1) while accounting for regional and decade effects (Column 4) and control variables that capture the dynamics of commodity booms over time (Column 5). The Schwartz Bayesian information criterion (SBIC) is computed as follows: SBIC = $2 * \log \operatorname{Lik}+k^{*} \log (N)$, where $k$ is the number of regressors and $N$ is the number of spells. 
Table 4. Duration of commodity price booms II.

\begin{tabular}{|c|c|c|c|c|c|c|c|c|}
\hline & (1) & (2) & (3) & (4) & (5) & (6) & (7) & (8) \\
\hline$\gamma$ & $\begin{array}{c}0.0003 \\
(0.0002)\end{array}$ & $\begin{array}{c}0.0001 \\
(0.0002)\end{array}$ & $\begin{array}{c}0.0004 \\
(0.0003)\end{array}$ & $\begin{array}{c}0.0002 \\
(0.0001)\end{array}$ & $\begin{array}{c}0.0001 \\
(0.0002)\end{array}$ & $\begin{array}{c}0.0003 \\
(0.0002)\end{array}$ & $\begin{array}{c}0.0001 \\
(0.0002)\end{array}$ & $\begin{array}{c}0.0004 \\
(0.0004)\end{array}$ \\
\hline$p$ & $\begin{array}{l}5.012^{+, i} \\
(0.395)\end{array}$ & $\begin{array}{l}5.296^{+, i} \\
(0.391)\end{array}$ & $\begin{array}{l}5.334^{+, i} \\
(0.393)\end{array}$ & $\begin{array}{l}5.367^{+, i} \\
(0.384)\end{array}$ & $\begin{array}{l}6.359^{+, i} \\
(0.819)\end{array}$ & $\begin{array}{l}5.726^{+, i} \\
(0.716)\end{array}$ & $\begin{array}{l}5.449^{+, i} \\
(0.389)\end{array}$ & $\begin{array}{l}5.378^{+, i} \\
(0.414)\end{array}$ \\
\hline$\Delta p$ & & & & & & & $\begin{array}{c}-0.200^{*} \\
(0.112)\end{array}$ & $\begin{array}{c}-0.251^{* *} \\
(0.118)\end{array}$ \\
\hline$p+\Delta p$ & & & & & & & $\begin{array}{l}5.249^{+, i} \\
(0.381)\end{array}$ & $\begin{array}{l}5.127^{+, i} \\
(0.464)\end{array}$ \\
\hline Event & $\begin{array}{c}0.106 \\
(0.177)\end{array}$ & $\begin{array}{c}0.170 \\
(0.178)\end{array}$ & $\begin{array}{c}0.176 \\
(0.175)\end{array}$ & $\begin{array}{c}0.153 \\
(0.175)\end{array}$ & $\begin{array}{c}0.621 \\
(0.400)\end{array}$ & $\begin{array}{c}0.299 \\
(0.329)\end{array}$ & $\begin{array}{c}0.157 \\
(0.176)\end{array}$ & $\begin{array}{c}0.153 \\
(0.177)\end{array}$ \\
\hline Prev & $\begin{array}{c}-0.161 \\
(0.273)\end{array}$ & $\begin{array}{c}0.130 \\
(0.319)\end{array}$ & $\begin{array}{c}0.110 \\
(0.317)\end{array}$ & $\begin{array}{c}0.164 \\
(0.323)\end{array}$ & $\begin{array}{l}1.629 * * \\
(0.801)\end{array}$ & $\begin{array}{c}0.076 \\
(0.433)\end{array}$ & $\begin{array}{c}0.129 \\
(0.321)\end{array}$ & $\begin{array}{c}0.160 \\
(0.296)\end{array}$ \\
\hline DurPrev & $\begin{array}{l}-0.005 \\
(0.021)\end{array}$ & $\begin{array}{l}-0.018 \\
(0.021)\end{array}$ & $\begin{array}{l}-0.014 \\
(0.022)\end{array}$ & $\begin{array}{l}-0.014 \\
(0.022)\end{array}$ & $\begin{array}{c}0.063 \\
(0.105)\end{array}$ & $\begin{array}{l}-0.037 \\
(0.024)\end{array}$ & $\begin{array}{l}-0.014 \\
(0.022)\end{array}$ & $\begin{array}{l}-0.014 \\
(0.022)\end{array}$ \\
\hline RGDPgr & $\begin{array}{l}3.830^{*} \\
(2.318)\end{array}$ & $\begin{array}{c}6.778^{* * *} \\
(3.216)\end{array}$ & $\begin{array}{c}6.452 * * \\
(3.270)\end{array}$ & $\begin{array}{l}6.102^{*} \\
(3.271)\end{array}$ & $\begin{array}{c}0.455 \\
(7.532)\end{array}$ & $\begin{array}{l}19.583^{*} \\
(11.518)\end{array}$ & $\begin{array}{l}5.794^{*} \\
(3.406)\end{array}$ & $\begin{array}{l}6.060^{*} \\
(3.449)\end{array}$ \\
\hline Inflation & $\begin{array}{c}-9.131 * * * \\
(1.077)\end{array}$ & $\begin{array}{c}-9.156^{* * *} \\
(1.210)\end{array}$ & $\begin{array}{c}-9.702 * * * \\
(1.223)\end{array}$ & $\begin{array}{c}-9.237 * * * \\
(1.164)\end{array}$ & $\begin{array}{l}-9.492 \\
(6.139)\end{array}$ & $\begin{array}{c}5.501 \\
(15.324)\end{array}$ & $\begin{array}{c}-9.183 * * * \\
(1.165)\end{array}$ & $\begin{array}{c}-9.231 * * * \\
(1.177)\end{array}$ \\
\hline InterestRate & $\begin{array}{c}2.748 * * * \\
(0.744)\end{array}$ & $\begin{array}{c}1.618 * * * \\
(0.454)\end{array}$ & $\begin{array}{c}1.460 * * * \\
(0.533)\end{array}$ & $\begin{array}{c}1.578 * * * \\
(0.492)\end{array}$ & $\begin{array}{c}0.670 \\
(3.417)\end{array}$ & $\begin{array}{l}-12.131 \\
(9.406)\end{array}$ & $\begin{array}{c}1.579 * * * \\
(0.482)\end{array}$ & $\begin{array}{c}1.578 * * * * \\
(0.491)\end{array}$ \\
\hline Liquidity & $\begin{array}{c}0.770 * * * \\
(0.218)\end{array}$ & $\begin{array}{c}0.909 * * * \\
(0.296)\end{array}$ & $\begin{array}{c}0.913 * * * \\
(0.296)\end{array}$ & $\begin{array}{c}0.875 * * * \\
(0.295)\end{array}$ & $\begin{array}{c}0.524 \\
(1.014)\end{array}$ & $\begin{array}{l}1.920 * * \\
(0.944)\end{array}$ & $\begin{array}{c}0.846^{* * * *} \\
(0.306)\end{array}$ & $\begin{array}{c}0.871^{* * * *} \\
(0.309)\end{array}$ \\
\hline Uncertainty & $\begin{array}{c}0.195 * * * \\
(0.039)\end{array}$ & $\begin{array}{c}0.185 * * * \\
(0.033)\end{array}$ & $\begin{array}{c}0.170 * * * \\
(0.037)\end{array}$ & $\begin{array}{c}0.182 * * * \\
(0.035)\end{array}$ & $\begin{array}{c}0.075 \\
(0.155)\end{array}$ & $\begin{array}{l}-0.166 \\
(0.234)\end{array}$ & $\begin{array}{c}0.176^{* * * *} \\
(0.035)\end{array}$ & $\begin{array}{c}0.181^{* * * *} \\
(0.037)\end{array}$ \\
\hline Violence & $\begin{array}{c}0.461 \\
(0.413)\end{array}$ & $\begin{array}{c}0.693 * * * \\
(0.212)\end{array}$ & $\begin{array}{c}0.792 * * * \\
(0.244)\end{array}$ & $\begin{array}{c}0.780 * * * \\
(0.223)\end{array}$ & $\begin{array}{l}2.253^{*} \\
(1.204)\end{array}$ & $\begin{array}{c}6.070 \\
(4.062)\end{array}$ & $\begin{array}{c}0.767 * * * \\
(0.223)\end{array}$ & $\begin{array}{c}0.779 * * * * \\
(0.221)\end{array}$ \\
\hline Temperature & & $\begin{array}{c}-4.859^{* *} \\
(2.445)\end{array}$ & $\begin{array}{l}-4.590^{*} \\
(2.547)\end{array}$ & $\begin{array}{l}-4.484^{*} \\
(2.456)\end{array}$ & $\begin{array}{l}-6.265 \\
(7.709)\end{array}$ & $\begin{array}{c}-20.453^{*} \\
(10.887)\end{array}$ & $\begin{array}{l}-4.363^{*} \\
(2.492)\end{array}$ & $\begin{array}{l}-4.467^{*} \\
(2.476)\end{array}$ \\
\hline Rainfall & & $\begin{array}{c}0.807 * * \\
(0.318)\end{array}$ & $\begin{array}{c}0.821 * * \\
(0.361)\end{array}$ & $\begin{array}{c}0.775 * * \\
(0.337)\end{array}$ & $\begin{array}{l}1.221 \\
(1.182)\end{array}$ & $\begin{array}{c}2.720 * * * * \\
(0.787)\end{array}$ & $\begin{array}{c}0.749 * * \\
(0.341)\end{array}$ & $\begin{array}{c}0.771 * * \\
(0.346)\end{array}$ \\
\hline HighIncome & & & $\begin{array}{l}-0.426 \\
(0.280)\end{array}$ & & & & & \\
\hline OECD & & & & $\begin{array}{c}-0.544^{* *} \\
(0.259)\end{array}$ & & & & $\begin{array}{l}-0.480 \\
(0.972)\end{array}$ \\
\hline \#Spells & 95 & 95 & 95 & 95 & 49 & 46 & 95 & 95 \\
\hline LogLik & 3.55 & 9.35 & 10.26 & 10.99 & 14.99 & 13.07 & -214.44 & -214.36 \\
\hline SBIC & 70.32 & 67.82 & 70.56 & 69.09 & 32.29 & 31.30 & 519.96 & 524.31 \\
\hline
\end{tabular}

Notes: See Table 3. Heteroscedasticity and serial correlation robust standard errors clustered by country are reported in parenthesis; + indicates that $p$ is significantly higher than 1 using a one-sided test with a $5 \%$ significance level; $d, c$, and $i$ indicate decreasing, constant and increasing positive duration dependence, respectively; ***,**,*- statistical significance at the $1 \%, 5 \%$, and $10 \%$ level, respectively. Regional and decade effects are accounted for in all estimations but not reported here to save space. Columns 1 and 2 report results with additional global economic and environmental variables. The regressors RGDPgr, Inflation, InterestRate and Uncertainty refer to the U.S. and are used as proxies for global economy developments. Liquidity corresponds to global liquidity. All variables, including Violence, Temperature and Rainfall, are measured as averages over each spell. Columns 3 and 4 account for each country's income level (i.e. the HighIncome dummy variable) and its level of development (namely, the $O E C D$ dummy variable), respectively. The results presented in Columns 5 and 6 are for the subsample of non-OECD and OECD countries, respectively. In Columns 7 and 8 , we estimate the difference in the duration dependence parameter between OECD and non-OECD countries $(\Delta p)$. Hence, $p$ and $p+\Delta p$ represent the value of the duration dependence parameter for the group of non-OECD and OECD countries, respectively. 
Table 5. Duration of commodity price busts $I$.

\begin{tabular}{|c|c|c|c|c|c|}
\hline & (1) & (2) & (3) & (4) & (5) \\
\hline$\gamma$ & $\begin{array}{c}0.0014 * * \\
(0.0006)\end{array}$ & $\begin{array}{l}0.0025^{*} \\
(0.0013)\end{array}$ & $\begin{array}{c}0.0014 * * \\
(0.0006)\end{array}$ & $\begin{array}{c}0.0002 \\
(0.0001)\end{array}$ & $\begin{array}{c}0.0003 \\
(0.0003)\end{array}$ \\
\hline$p$ & $\begin{array}{l}2.371^{+, i} \\
(0.136)\end{array}$ & $\begin{array}{l}2.171^{+, c} \\
(0.170)\end{array}$ & $\begin{array}{l}2.372^{+, \mathrm{i}} \\
(0.109)\end{array}$ & $\begin{array}{l}3.713^{+, \hat{i}} \\
(0.286)\end{array}$ & $\begin{array}{l}3.576^{+, i} \\
(0.300)\end{array}$ \\
\hline$\theta$ & & & $\begin{array}{c}0.653 \\
(1.080)\end{array}$ & & \\
\hline EAP & & & & $\begin{array}{c}-0.296 \\
(0.288)\end{array}$ & $\begin{array}{c}-0.482 * * \\
(0.229)\end{array}$ \\
\hline ECA & & & & $\begin{array}{c}-0.094 \\
(0.280)\end{array}$ & $\begin{array}{l}-0.311 \\
(0.235)\end{array}$ \\
\hline LAC & & & & $\begin{array}{c}0.051 \\
(0.301)\end{array}$ & $\begin{array}{c}-0.067 \\
(0.280)\end{array}$ \\
\hline MENA & & & & $\begin{array}{c}-0.734 * * * \\
(0.242)\end{array}$ & $\begin{array}{c}-1.105^{* * *} \\
(0.291)\end{array}$ \\
\hline NAM & & & & $\begin{array}{c}0.099 \\
(0.287)\end{array}$ & $\begin{array}{c}-0.254 \\
(0.254)\end{array}$ \\
\hline Decade 90 & & & & $\begin{array}{c}1.117 * * * \\
(0.230)\end{array}$ & $\begin{array}{c}0.963 * * * \\
(0.300)\end{array}$ \\
\hline Decade00 & & & & $\begin{array}{c}4.920 * * * \\
(0.499)\end{array}$ & $\begin{array}{c}5.130 * * * \\
(0.491)\end{array}$ \\
\hline Event & & & & & $\begin{array}{l}-0.161 \\
(0.115)\end{array}$ \\
\hline Prev & & & & & $\begin{array}{c}0.276 \\
(0.504)\end{array}$ \\
\hline DurPrev & & & & & $\begin{array}{c}0.010 \\
(0.010) \\
\end{array}$ \\
\hline \#Spells & 136 & 136 & 136 & 136 & 136 \\
\hline LogLik & -106.6 & -361.5 & -106.6 & -46.75 & -43.86 \\
\hline $\begin{array}{l}\text { SBIC } \\
\text { LR-test }\end{array}$ & 223.1 & 732.7 & $\begin{array}{l}228.0 \\
0.873\end{array}$ & 132.8 & 141.8 \\
\hline
\end{tabular}

Notes: See Table 3. Heteroscedasticity and serial correlation robust standard errors clustered by country are reported in parenthesis; + indicates that $p$ is significantly higher than 1 using a one-sided test with a $5 \%$ significance level; $d, c$, and $i$ indicate decreasing, constant and increasing positive duration dependence, respectively; $* * *, * *, *-$ statistical significance at the $1 \%, 5 \%$, and $10 \%$ level, respectively. Due to the lack of variability, SAS and Decade 80 are automatically excluded from the regressions. Column 1 reports results for a basic Weibull specification. Truncation at the minimum value of the observed duration of busts (i.e. five quarters) is used in regressions presented in Column 2. In Column 3, the $p$-value of the LR test for unobserved heterogeneity/frailty assesses whether the estimated variance $(\theta)$ is different from zero or not. Columns 4 and 5 report extensions to the basic model (1) while accounting for regional and decade effects (Column 4) and control variables that capture the dynamics of commodity busts over time (Column 5). The Schwartz Bayesian information criterion (SBIC) is computed as follows: $\mathrm{SBIC}=-2 * \log \operatorname{Lik}+k^{*} \log (N)$, where $k$ is the number of regressors and $N$ is the number of spells. 
Table 6. Duration of commodity prices busts II.

\begin{tabular}{|c|c|c|c|c|c|c|c|c|}
\hline & (1) & (2) & (3) & (4) & (5) & (6) & (7) & (8) \\
\hline \multirow[t]{2}{*}{$\gamma$} & 0.0001 & 0.0001 & 0.0004 & 0.0001 & 0.0001 & 0.0002 & 0.0001 & 0.0001 \\
\hline & $(0.0002)$ & $(0.0002)$ & $(0.0003)$ & $(0.0002)$ & $(0.0002)$ & $(0.0002)$ & $(0.0002)$ & (0.0002) \\
\hline \multirow[t]{2}{*}{$p$} & $5.857^{+, i}$ & $6.454^{+, i}$ & $6.468^{+, i}$ & $6.479^{+, i}$ & $7.201^{+, i}$ & $6.138^{+, i}$ & $6.573^{+, i}$ & $6.816^{+, i}$ \\
\hline & (0.569) & (0.800) & (0.792) & $(0.812)$ & (2.157) & (0.815) & $(0.833)$ & $(0.837)$ \\
\hline \multirow[t]{2}{*}{$\Delta p$} & & & & & & & -0.114 & -0.466 \\
\hline & & & & & & & $(0.150)$ & (0.380) \\
\hline \multirow[t]{2}{*}{$p+\Delta p$} & & & & & & & $6.459^{+, i}$ & $6.350^{+, i}$ \\
\hline & & & & & & & (0.806) & $(0.818)$ \\
\hline \multirow[t]{2}{*}{ Event } & $0.219 * *$ & $0.289 * *$ & $0.313^{* *}$ & $0.299 * *$ & 0.463 & 0.354 & $0.291 * *$ & $0.251^{* *}$ \\
\hline & (0.106) & $(0.121)$ & $(0.127)$ & $(0.119)$ & $(0.306)$ & $(0.239)$ & (0.115) & $(0.120)$ \\
\hline \multirow[t]{2}{*}{ Prev } & -0.437 & -0.464 & -0.547 & -0.480 & -0.394 & $-3.290 * * *$ & -0.476 & -0.440 \\
\hline & $(0.562)$ & $(0.542)$ & (0.619) & $(0.551)$ & (0.482) & (0.914) & $(0.562)$ & (0.600) \\
\hline \multirow[t]{2}{*}{ DurPrev } & $0.033^{* * *}$ & $0.022 *$ & $0.021 *$ & $0.023^{*}$ & 0.039 & 0.022 & $0.023^{*}$ & $0.021 *$ \\
\hline & $(0.011)$ & $(0.012)$ & (0.012) & (0.012) & (0.037) & (0.016) & (0.012) & $(0.012)$ \\
\hline \multirow[t]{2}{*}{ RGDPgr } & $1.326^{* *}$ & $1.530 * *$ & $1.479 * *$ & $1.519 * *$ & 1.874 & $1.736^{*}$ & $1.519 * *$ & $1.541 * *$ \\
\hline & $(0.591)$ & (0.653) & (0.676) & (0.659) & (1.264) & (0.905) & (0.665) & $(0.668)$ \\
\hline \multirow[t]{2}{*}{ Inflation } & $-1.551 * *$ & -1.104 & -1.156 & -1.111 & $-2.937 * *$ & -0.635 & -1.116 & -1.115 \\
\hline & $(0.775)$ & (0.857) & (0.892) & (0.880) & $(1.265)$ & (1.101) & $(0.892)$ & $(0.888)$ \\
\hline \multirow[t]{2}{*}{ InterestRate } & $2.105^{* * *}$ & $2.432 * * *$ & $2.448 * * *$ & $2.426 * * *$ & $5.134 * * * *$ & $2.063 * * *$ & $2.431^{* * *}$ & $2.456 * * *$ \\
\hline & $(0.337)$ & $(0.462)$ & $(0.459)$ & $(0.462)$ & $(0.849)$ & $(0.486)$ & $(0.464)$ & $(0.466)$ \\
\hline \multirow[t]{2}{*}{ Liquidity } & $0.710^{* * *}$ & $0.990^{* * * *}$ & $0.981^{* * *}$ & $0.988 * * *$ & $1.997 * * *$ & $0.912 * * *$ & $0.995 * * *$ & $1.018 * * *$ \\
\hline & $(0.149)$ & $(0.220)$ & $(0.226)$ & $(0.223)$ & $(0.703)$ & $(0.289)$ & $(0.227)$ & $(0.232)$ \\
\hline \multirow[t]{2}{*}{ Uncertainty } & 0.032 & -0.025 & -0.027 & -0.026 & -0.083 & $-0.072^{* *}$ & -0.028 & -0.030 \\
\hline & $(0.038)$ & $.035)$ & (0.036) & (0.036) & $(0.06$ & & $(0.036)$ & $(0.035)$ \\
\hline \multirow[t]{2}{*}{ Violence } & $0.576^{* * *}$ & $0.611 * * *$ & $0.615^{* * *}$ & $0.611^{* * *}$ & $1.465 * * *$ & $0.614 * * *$ & $0.612 * * *$ & $0.614 * * *$ \\
\hline & $(0.155)$ & $(0.206)$ & $(0.205)$ & $(0.203)$ & $(0.238)$ & $(0.204)$ & $(0.200)$ & (0.194) \\
\hline \multirow[t]{2}{*}{ Temperature } & & 0.988 & 0.990 & 0.897 & $3.533 * *$ & -0.770 & 0.851 & 0.877 \\
\hline & & $(1.030)$ & (1.038) & (1.054) & (1.413) & (1.171) & (1.054) & $(1.060)$ \\
\hline \multirow[t]{2}{*}{ Rainfall } & & $-0.578 * * *$ & $-0.583 * * *$ & $-0.581 * * *$ & $-0.819^{*}$ & $-0.825^{* *}$ & $-0.590 * * *$ & $-0.612 * * *$ \\
\hline & & $(0.175)$ & $(0.177)$ & $(0.181)$ & $(0.465)$ & $(0.365)$ & $(0.188)$ & $(0.193)$ \\
\hline \multirow[t]{2}{*}{ HighIncome } & & & -0.220 & & & & & \\
\hline & & & $(0.325)$ & & & & & \\
\hline \multirow[t]{2}{*}{ OECD } & & & & -0.199 & & & & 0.974 \\
\hline & & & & $(0.370)$ & & & & (0.904) \\
\hline \#Spells & 127 & 127 & 127 & 127 & 62 & $0 J$ & 127 & 127 \\
\hline LogLik & 16.99 & 24.15 & 24.40 & 24.35 & 31.86 & 12.33 & -213.30 & -212.89 \\
\hline SBIC & 48.38 & 43.74 & 48.09 & 48.19 & -1.81 & 47.12 & 523.49 & 527.51 \\
\hline
\end{tabular}

Notes: See Tables 3-5. Heteroscedasticity and serial correlation robust standard errors clustered by country are reported in parenthesis; + indicates that $p$ is significantly higher than 1 using a one-sided test with a $5 \%$ significance level; $d, c$, and $i$ indicate decreasing, constant and increasing positive duration dependence, respectively; $* * *, * *, *$ - statistical significance at the $1 \%, 5 \%$, and $10 \%$ level, respectively. Regional and decade effects are accounted for in all estimations but not reported here to save space. Columns 1 and 2 report results with additional global economic and environmental variables. The regressors RGDPgr, Inflation, InterestRate and Uncertainty refer to the U.S. and are used as proxies for global economy developments. Liquidity corresponds to global liquidity. All variables, including Violence, Temperature and Rainfall are measured as averages over each spell. Regressions 3 and 4 account for each country's income level (i.e. the HighIncome dummy variable) and its level of development (namely, the $O E C D$ dummy variable), respectively. The results presented in Columns 5 and 6 are for the subsample of non-OECD and OECD countries, respectively. In Columns 7 and 8, we estimate the difference in the duration dependence parameter between OECD and non-OECD countries $(\Delta p)$. Hence, $p$ and $p+\Delta p$ represent the value of the duration dependence parameter for the group of nonOECD and OECD countries, respectively. 
Table 7. Duration of commodity price normal times I.

\begin{tabular}{|c|c|c|c|c|}
\hline & $(1)$ & (2) & (3) & (4) \\
\hline$\gamma$ & $\begin{array}{c}0.0865 * * * \\
(0.0106)\end{array}$ & $\begin{array}{c}0.0772 * * * \\
(0.0134)\end{array}$ & $\begin{array}{c}0.1026 * * * \\
(0.0292)\end{array}$ & $\begin{array}{c}0.0010 \\
(0.0011)\end{array}$ \\
\hline$p$ & $\begin{array}{c}1.010 \\
(0.051)\end{array}$ & $\begin{array}{l}1.757^{+, \mathrm{d}} \\
(0.124)\end{array}$ & $\begin{array}{c}1.085 \\
(0.054)\end{array}$ & $\begin{array}{l}1.613^{+, \mathrm{d}} \\
(0.073)\end{array}$ \\
\hline$\theta$ & & $\begin{array}{c}7.972 * * * \\
(2.872)\end{array}$ & & \\
\hline EAP & & & $\begin{array}{c}-0.616^{* * *} * \\
(0.179)\end{array}$ & $\begin{array}{l}-0.135 \\
(0.261)\end{array}$ \\
\hline ECA & & & $\begin{array}{c}-0.386^{* * *} \\
(0.125)\end{array}$ & $\begin{array}{c}0.201 \\
(0.203)\end{array}$ \\
\hline LAC & & & $\begin{array}{c}-0.403 * * \\
(0.203)\end{array}$ & $\begin{array}{c}0.212 \\
(0.238)\end{array}$ \\
\hline MENA & & & $\begin{array}{c}-0.842 * * * \\
(0.064)\end{array}$ & $\begin{array}{c}1.286^{* * *} \\
(0.286)\end{array}$ \\
\hline NAM & & & $\begin{array}{c}-0.342 * * \\
(0.172)\end{array}$ & $\begin{array}{c}0.538 \\
(0.341)\end{array}$ \\
\hline SAS & & & $\begin{array}{c}-0.539 * * * \\
(0.053)\end{array}$ & $\begin{array}{l}-0.203 \\
(0.280)\end{array}$ \\
\hline Decade80 & & & $\begin{array}{c}0.502 \\
(0.353)\end{array}$ & $\begin{array}{c}3.244 * * * \\
(0.599)\end{array}$ \\
\hline Decade90 & & & $\begin{array}{l}-0.554 \\
(0.372)\end{array}$ & $\begin{array}{c}1.492 * * * \\
(0.522)\end{array}$ \\
\hline Decade00 & & & $\begin{array}{c}0.237 \\
(0.248)\end{array}$ & $\begin{array}{c}1.414 * * * \\
(0.333)\end{array}$ \\
\hline Event & & & & $\begin{array}{c}0.825 * * * \\
(0.161)\end{array}$ \\
\hline Prev & & & & $\begin{array}{c}0.545^{* *} \\
(0.256)\end{array}$ \\
\hline DurPrev & & & & $\begin{array}{l}0.017 * \\
(0.009) \\
\end{array}$ \\
\hline \#Spells & 169 & 169 & 169 & 136 \\
\hline LogLik & -257.7 & -252.8 & -244.0 & -148.9 \\
\hline $\begin{array}{l}\text { SBIC } \\
\text { LR-test }\end{array}$ & 525.7 & $\begin{array}{l}521.0 \\
0.006\end{array}$ & 529.0 & 351.9 \\
\hline
\end{tabular}

Notes: See Tables 3-6. As the minimum observed duration for normal times is 1, truncation is not considered. Hence, Column 2, reports the frailty estimation and respective test; in Column 3, we account for country-specific effects; and Columns 5-6 report extensions to the basic model (1). Heteroscedasticity and serial correlation robust standard errors clustered by country are reported in parenthesis; + indicates that $p$ is significantly higher than 1 using a one-sided test with a 5\% significance level; $d, c$, and $i$ indicate decreasing, constant and increasing positive duration dependence, respectively; $* * *, * *, *-$ statistical significance at the $1 \%, 5 \%$, and $10 \%$ level, respectively. Due to the lack of variability, SAS and Decade80 are automatically excluded from the regressions. Column 1 reports results for a basic Weibull specification. As the minimum observed duration for normal times is 1 (i.e. one quarter), truncation is not considered. In Column 2, the $p$-value of the LR test for unobserved heterogeneity/frailty assesses whether the estimated variance $(\theta)$ is different from zero or not. Columns 3 and 4 report extensions to the basic model (1) while accounting for regional and decade effects (Column 3 ) and control variables that capture the dynamics of commodity price' normal times spells over time (Column 4). The Schwartz Bayesian information criterion (SBIC) is computed as follows: SBIC $=-2 * \log \operatorname{Lik}+k^{*} \log (N)$, where $k$ is the number of regressors and $N$ is the number of spells. 
Table 8. Duration of commodity prices normal times II.

\begin{tabular}{|c|c|c|c|c|c|c|c|c|}
\hline & (1) & (2) & (3) & (4) & (5) & (6) & (7) & (8) \\
\hline$\gamma$ & $\begin{array}{c}0.0013 \\
(0.0015)\end{array}$ & $\begin{array}{c}0.0022 \\
(0.0024)\end{array}$ & $\begin{array}{c}0.0024 \\
(0.0032)\end{array}$ & $\begin{array}{c}0.0021 \\
(0.0027)\end{array}$ & $\begin{array}{c}0.0005 \\
(0.0167)\end{array}$ & $\begin{array}{c}0.0004 \\
(0.0006)\end{array}$ & $\begin{array}{c}0.0386 \\
(0.0501)\end{array}$ & $\begin{array}{c}0.0693 \\
(0.0906)\end{array}$ \\
\hline$p$ & $\begin{array}{l}2.148^{+, \hat{c}} \\
(0.136)\end{array}$ & $\begin{array}{l}2.273^{+, i} \\
(0.154)\end{array}$ & $\begin{array}{l}2.284^{+, i} \\
(0.164)\end{array}$ & $\begin{array}{l}2.275^{+, i} \\
(0.156)\end{array}$ & $\begin{array}{l}2.777^{+i} \\
(0.311)\end{array}$ & $\begin{array}{l}2.389^{+, \mathcal{c}} \\
(0.460)\end{array}$ & $\begin{array}{l}2.345^{+, i} \\
(0.178)\end{array}$ & $\begin{array}{l}2.486^{+, i} \\
(0.214)\end{array}$ \\
\hline$\Delta p$ & & & & & & & $\begin{array}{c}-0.209 * * * \\
(0.081)\end{array}$ & $\begin{array}{c}-0.389 * * * * \\
(0.106)\end{array}$ \\
\hline$p+\Delta p$ & & & & & & & $\begin{array}{l}2.135^{+, \mathrm{c}} \\
(0.154)\end{array}$ & $\begin{array}{l}2.097^{+, \mathrm{c}} \\
(0.149)\end{array}$ \\
\hline Event & $\begin{array}{c}0.852 * * * \\
(0.149)\end{array}$ & $\begin{array}{c}0.874 * * * * \\
(0.156)\end{array}$ & $\begin{array}{c}0.899 * * * \\
(0.158)\end{array}$ & $\begin{array}{c}0.874 * * * \\
(0.159)\end{array}$ & $\begin{array}{c}1.287 * * \\
(0.516)\end{array}$ & $\begin{array}{c}0.756^{* * *} \\
(0.246)\end{array}$ & $\begin{array}{c}0.882^{* * * *} \\
(0.164)\end{array}$ & $\begin{array}{c}0.936^{* * * *} \\
(0.156)\end{array}$ \\
\hline Prev & $\begin{array}{l}-0.149 \\
(0.254)\end{array}$ & & $\begin{array}{r}0.0 \\
(0.3\end{array}$ & $\begin{array}{r}0.0 \\
(0.3\end{array}$ & $\begin{array}{c}0.4 \\
(0.6\end{array}$ & & $\begin{array}{r}0.0 \\
(0.3\end{array}$ & $\begin{array}{l}-0.108 \\
(0.282)\end{array}$ \\
\hline DurPrev & $\begin{array}{c}0.001 \\
(0.014)\end{array}$ & & $\begin{array}{r}0.00 \\
(0.01\end{array}$ & $\begin{array}{c}0.005 \\
(0.016)\end{array}$ & $\begin{array}{r}0.101^{*} \\
(0.03\end{array}$ & & $\begin{array}{l}0.0 \\
(0 . C\end{array}$ & $\begin{array}{c}0.002 \\
(0.014)\end{array}$ \\
\hline RGDPgr & & & & $\begin{array}{l}-0.160 \\
(0.436)\end{array}$ & $\begin{array}{c}0.410 \\
(1.347)\end{array}$ & & & \\
\hline Inflation & $\begin{array}{c}1.374 * * * \\
(0.525)\end{array}$ & $\begin{array}{c}1.920 * * * \\
(0.582)\end{array}$ & $\begin{array}{c}1.945 * * * \\
(0.599)\end{array}$ & $\begin{array}{c}1.919 * * * \\
(0.588)\end{array}$ & $\begin{array}{c}1.392 \\
(1.080)\end{array}$ & $\begin{array}{c}2.374 * * * \\
(0.694)\end{array}$ & $\begin{array}{c}1.957^{* * * *} \\
(0.605)\end{array}$ & $\begin{array}{c}2.107 * * * * \\
(0.618)\end{array}$ \\
\hline InterestRate & $\begin{array}{c}-0.720 * * * \\
(0.172)\end{array}$ & $\begin{array}{c}-1.082 * * * \\
(0.239)\end{array}$ & $\begin{array}{c}-1.112^{* * *} \\
(0.256)\end{array}$ & $\begin{array}{c}-1.080 * * * \\
(0.244)\end{array}$ & $\begin{array}{c}-1.148 * * \\
(0.568)\end{array}$ & $\begin{array}{c}-2.012^{* *} \\
(0.947)\end{array}$ & $\begin{array}{c}-1.078^{* * *} \\
(0.254)\end{array}$ & $\begin{array}{c}-1.144 * * * \\
(0.236)\end{array}$ \\
\hline Liquidity & $\begin{array}{c}-0.149^{*} \\
(0.089)\end{array}$ & & $\begin{array}{c}-0.213^{* *} \\
(0.102)\end{array}$ & $\begin{array}{c}-0.210^{* *} \\
(0.094)\end{array}$ & $\begin{array}{l}-0.112 \\
(0.222)\end{array}$ & $\begin{array}{c}-0.369 * * * \\
(0.119)\end{array}$ & $\begin{array}{c}-0.215^{* *} \\
(0.099)\end{array}$ & $\begin{array}{c}-0.231 * * \\
(0.100)\end{array}$ \\
\hline Uncertainty & $\begin{array}{c}-0.033^{*} \\
(0.017)\end{array}$ & $\begin{array}{c}-0.038^{* *} \\
(0.017)\end{array}$ & $\begin{array}{c}-0.039 * * \\
(0.019)\end{array}$ & $\begin{array}{c}-0.037^{* *} \\
(0.018)\end{array}$ & $\begin{array}{l}-0.011 \\
(0.060)\end{array}$ & $\begin{array}{c}-0.058 * * * * \\
(0.020)\end{array}$ & $\begin{array}{c}-0.040 * * \\
(0.018)\end{array}$ & $\begin{array}{c}-0.049 * * \\
(0.019)\end{array}$ \\
\hline Violence & $\begin{array}{c}-0.547 * * * \\
(0.144)\end{array}$ & $\begin{array}{c}-0.575^{* * *} \\
(0.144)\end{array}$ & $\begin{array}{c}-0.571 * * * \\
(0.149)\end{array}$ & $\begin{array}{c}-0.574 * * * \\
(0.144)\end{array}$ & $\begin{array}{c}-0.541 * * \\
(0.254)\end{array}$ & $\begin{array}{c}-1.073^{* * *} \\
(0.267)\end{array}$ & $\begin{array}{c}-0.572 * * * \\
(0.147)\end{array}$ & $\begin{array}{c}-0.582 * * * * \\
(0.149)\end{array}$ \\
\hline Temperature & & $\begin{array}{c}0.586 \\
(0.784)\end{array}$ & $\begin{array}{c}0.548 \\
(0.779)\end{array}$ & $\begin{array}{c}0.611 \\
(0.820)\end{array}$ & $\begin{array}{c}1.401 \\
(1.114)\end{array}$ & $\begin{array}{c}1.141 \\
(2.028)\end{array}$ & $\begin{array}{c}0.685 \\
(0.847)\end{array}$ & $\begin{array}{c}0.521 \\
(0.647)\end{array}$ \\
\hline Rainfall & & $\begin{array}{c}0.020 \\
(0.139)\end{array}$ & $\begin{array}{c}0.025 \\
(0.139)\end{array}$ & $\begin{array}{c}0.015 \\
(0.145)\end{array}$ & $\begin{array}{c}0.114 \\
(0.224)\end{array}$ & $\begin{array}{c}0.312 \\
(0.377)\end{array}$ & $\begin{array}{c}0.121 \\
(0.151)\end{array}$ & $\begin{array}{c}0.111 \\
(0.036)\end{array}$ \\
\hline HighIncome & & & $\begin{array}{l}-0.251 \\
(0.325)\end{array}$ & & & & & \\
\hline OECD & & & & $\begin{array}{l}-0.094 \\
(0.221)\end{array}$ & & & & $\begin{array}{c}0.093 \\
(0.542)\end{array}$ \\
\hline & & & & & & & & \\
\hline & & & & & -37 & & & \\
\hline SBIC & 290.24 & 286.91 & 290.89 & 291.64 & 137.32 & 146.31 & 830.31 & 828.98 \\
\hline
\end{tabular}

Notes: See Tables 3-7. Heteroscedasticity and serial correlation robust standard errors clustered by country are reported in parenthesis; + indicates that $p$ is significantly higher than 1 using a one-sided test with a $5 \%$ significance level; $d, c$, and $i$ indicate decreasing, constant and increasing positive duration dependence, respectively; ***,**,* - statistical significance at the $1 \%, 5 \%$, and $10 \%$ level, respectively. Regional and decade effects are accounted for in all estimations but not reported here to save space. Columns 1 and 2 report results with additional global economic and environmental variables. The regressors RGDPgr, Inflation, InterestRate and Uncertainty refer to the U.S. and are used as proxies for global economy developments. Liquidity corresponds to global liquidity. All variables, including Violence, Temperature and Rainfall, are measured as averages over each spell. Columns 3 and 4 account for each country's income level (i.e. the HighIncome dummy variable) and its level of development (namely, $O E C D$ dummy variable), respectively. The results presented in Columns 5 and 6 are for the subsample of non-OECD and OECD countries, respectively. In Columns 7 and 8 , we estimate the difference in the duration dependence parameter between OECD and non-OECD countries $(\Delta p)$. Hence, $p$ and $p+\Delta p$ represent the value of the duration dependence parameter for the group of non-OECD and OECD countries, respectively. 
Table 9. The impact of oil and energy prices on commodity price cycles.

\begin{tabular}{|c|c|c|c|c|c|c|}
\hline & \multicolumn{2}{|c|}{ Booms } & \multicolumn{2}{|c|}{ Busts } & \multicolumn{2}{|c|}{ Normal times } \\
\hline & (1) & (2) & (3) & (4) & (5) & (6) \\
\hline \multirow[t]{2}{*}{$\gamma$} & 0.0001 & 0.0001 & 0.0001 & 0.0002 & 0.0134 & 0.0011 \\
\hline & $(0.0001)$ & (0.0001) & $(0.0002)$ & $(0.0003)$ & $(0.0112)$ & $(0.0089)$ \\
\hline \multirow{2}{*}{$p$} & $4.800^{+, \hat{i}}$ & $4.929^{+, i}$ & $6.749^{+, \hat{i}}$ & $6.662^{+, i}$ & $1.883^{+, \mathrm{c}}$ & $2.242^{+, c}$ \\
\hline & (0.397) & $(0.362)$ & $(0.949)$ & $(2.743)$ & $(0.120)$ & $(0.164)$ \\
\hline \multirow[t]{2}{*}{ Event } & 0.076 & 0.082 & $0.347 * * *$ & $0.324 *$ & $0.427 * * *$ & $0.882 * * *$ \\
\hline & $(0.192)$ & $(0.183)$ & $(0.098)$ & $(0.168)$ & $(0.156)$ & $(0.172)$ \\
\hline \multirow[t]{2}{*}{ Prev } & 0.013 & 0.114 & -0.476 & -0.005 & 0.297 & 0.174 \\
\hline & $(0.269)$ & $(0.283)$ & $(0.578)$ & $(0.253)$ & $(0.332)$ & $(0.520)$ \\
\hline \multirow[t]{2}{*}{ DurPrev } & -0.006 & -0.006 & $0.023 * *$ & $0.043^{* * *}$ & -0.004 & -0.002 \\
\hline & $(0.021)$ & $(0.021)$ & $(0.010)$ & $(0.015)$ & $(0.011)$ & $(0.016)$ \\
\hline \multirow[t]{2}{*}{ RGDPgr } & 1.701 & 0.133 & $1.821 * *$ & $7.194 * * *$ & $-0.670^{*}$ & -0.320 \\
\hline & (1.189) & (1.382) & $(0.857)$ & $(2.055)$ & $(0.371)$ & $(0.362)$ \\
\hline \multirow[t]{2}{*}{ Inflation } & $-3.988 * * *$ & $-3.206^{*}$ & -0.745 & 0.048 & $1.388 * * *$ & $2.182 * * *$ \\
\hline & $(0.901)$ & (1.684) & $(1.082)$ & (3.946) & $(0.326)$ & $(0.403)$ \\
\hline \multirow[t]{2}{*}{ InterestRate } & 0.629 & 1.537 & $2.433 * * *$ & -3.065 & $-0.368^{*}$ & $-1.260 * * *$ \\
\hline & $(0.620)$ & (0.944) & $(0.390)$ & $(1.914)$ & $(0.213)$ & $(0.298)$ \\
\hline \multirow[t]{2}{*}{ Liquidity } & $0.706 * * *$ & 0.561 & $1.148 * * *$ & $3.814 * * *$ & $-0.210 * *$ & -0.113 \\
\hline & $(0.238)$ & $(0.432)$ & $(0.273)$ & $(0.507)$ & $(0.092)$ & $(0.110)$ \\
\hline \multirow[t]{2}{*}{ Uncertainty } & 0.066 & $0.144^{* *}$ & $0.131 * * *$ & $0.385^{* * *}$ & $-0.037 * * *$ & $-0.056 * * *$ \\
\hline & $(0.065)$ & $(0.067)$ & $(0.019)$ & $(0.059)$ & $(0.012)$ & $(0.013)$ \\
\hline \multirow[t]{2}{*}{ Violence } & $1.163 * * *$ & 0.864 & 0.036 & $1.044 * *$ & $-0.559 * * *$ & $-0.408 * *$ \\
\hline & $(0.230)$ & $(0.685)$ & $(0.176)$ & $(0.437)$ & $(0.146)$ & $(0.159)$ \\
\hline \multirow[t]{2}{*}{ Temperature } & -2.407 & -4.043 & 0.336 & $-5.082 * * *$ & -0.021 & -0.141 \\
\hline & $(2.261)$ & (3.722) & (0.687) & $(1.895)$ & $(0.789)$ & (1.270) \\
\hline \multirow[t]{2}{*}{ Rainfall } & 0.352 & 0.513 & $-0.439 *$ & 0.477 & 0.088 & 0.167 \\
\hline & $(0.403)$ & $(0.579)$ & $(0.225)$ & $(0.384)$ & $(0.155)$ & $(0.246)$ \\
\hline \multirow[t]{2}{*}{ Oilprice } & $-0.075^{* *}$ & & $-0.063 * * *$ & & -0.003 & \\
\hline & $(0.038)$ & & & & (0.008) & \\
\hline Energyprice & & $\begin{array}{l}-0.100 \\
(0.071)\end{array}$ & & $\begin{array}{c}-0.524 * * * \\
(0.081)\end{array}$ & & $\begin{array}{c}-0.026 * * \\
(0.010)\end{array}$ \\
\hline \#Spells & 95 & 93 & & 88 & 133 & 109 \\
\hline LogLik & -0.325 & 1.716 & 25.89 & 82.18 & -122.26 & -81.42 \\
\hline SBIC & 78.07 & 73.62 & 35.41 & -88.25 & 327.65 & 242.6 \\
\hline
\end{tabular}

Notes: See notes in Tables 3-8. Columns 1 and 2 report results for booms; columns 3 and 4 for busts; and columns 5 and 6 for normal times. OilPrice and EnergyPrice correspond to the crude oil price index and the fuel (energy) price index, respectively. Both variables are measured as the average over each spell. 
Table 10. Duration of commodity price booms - Sensitivity analysis.

\begin{tabular}{|c|c|c|c|c|c|}
\hline & $\begin{array}{l}\text { Geopolitical } \\
\text { risk }\end{array}$ & $\begin{array}{l}\text { Capital flow } \\
\text { boom-bust }\end{array}$ & Credit boom-bust & Median & Quartile \\
\hline & (1) & (2) & (3) & (4) & (5) \\
\hline$\gamma$ & $\begin{array}{c}0.0001 \\
(0.0001)\end{array}$ & $\begin{array}{c}0.0001 \\
(0.0001)\end{array}$ & $\begin{array}{c}0.0001 \\
(0.0001)\end{array}$ & $\begin{array}{c}0.0001 \\
(0.0002)\end{array}$ & $\begin{array}{c}0.0001 \\
(0.0001)\end{array}$ \\
\hline$p$ & $\begin{array}{l}4.651^{+, i} \\
(0.402)\end{array}$ & $\begin{array}{l}5.013^{+, i} \\
(0.396)\end{array}$ & $\begin{array}{l}5.143^{+, i} \\
(0.411)\end{array}$ & $\begin{array}{l}4.387^{+, i} \\
(0.317)\end{array}$ & $\begin{array}{l}5.673^{+, i} \\
(1.085)\end{array}$ \\
\hline Event & $\begin{array}{c}0.074 \\
(0.200)\end{array}$ & $\begin{array}{c}0.109 \\
(0.178)\end{array}$ & $\begin{array}{c}0.116 \\
(0.178)\end{array}$ & $\begin{array}{c}0.116 \\
(0.095)\end{array}$ & $\begin{array}{c}0.640 \\
(0.421)\end{array}$ \\
\hline Prev & $\begin{array}{l}-0.293 \\
(0.239)\end{array}$ & $\begin{array}{l}-0.214 \\
(0.261)\end{array}$ & $\begin{array}{l}-0.186 \\
(0.228)\end{array}$ & $\begin{array}{l}-0.142 \\
(0.237)\end{array}$ & $\begin{array}{c}0.320 \\
(0.374)\end{array}$ \\
\hline DurPrev & $\begin{array}{c}0.003 \\
(0.019)\end{array}$ & $\begin{array}{l}-0.004 \\
(0.021)\end{array}$ & $\begin{array}{l}-0.005 \\
(0.020)\end{array}$ & $\begin{array}{c}0.016 \\
(0.038)\end{array}$ & $\begin{array}{l}-0.009 \\
(0.010)\end{array}$ \\
\hline RGDPgr & $\begin{array}{c}-0.297 \\
(1.854)\end{array}$ & $\begin{array}{l}3.989^{*} \\
(2.302)\end{array}$ & $\begin{array}{c}2.907 \\
(2.118)\end{array}$ & $\begin{array}{c}5.173 * * * \\
(0.961)\end{array}$ & $\begin{array}{c}8.926 * * \\
(4.436)\end{array}$ \\
\hline Inflation & $\begin{array}{c}-4.516^{* * *} \\
(1.115)\end{array}$ & $\begin{array}{c}-9.547 * * * \\
(0.737)\end{array}$ & $\begin{array}{c}-12.217 * * * \\
(1.475)\end{array}$ & $\begin{array}{c}-3.193 * * \\
(1.581)\end{array}$ & $\begin{array}{c}-7.047 * * \\
(3.494)\end{array}$ \\
\hline InterestRate & $\begin{array}{c}2.721 * * \\
(1.352)\end{array}$ & $\begin{array}{c}3.098 * * * \\
(0.772)\end{array}$ & $\begin{array}{c}2.192 * * * \\
(0.698)\end{array}$ & $\begin{array}{c}2.173 * * * \\
(0.358)\end{array}$ & $\begin{array}{c}1.254 \\
(1.252)\end{array}$ \\
\hline Liquidity & $\begin{array}{l}0.371^{*} \\
(0.196)\end{array}$ & $\begin{array}{c}0.751 * * * \\
(0.225)\end{array}$ & $\begin{array}{c}0.901 * * * \\
(0.175)\end{array}$ & $\begin{array}{c}0.658 * * * \\
(0.138)\end{array}$ & $\begin{array}{l}1.078^{* * *} \\
(0.432)\end{array}$ \\
\hline Uncertainty & & $\begin{array}{c}0.206 * * * \\
(0.034)\end{array}$ & $\begin{array}{c}0.137 * * * \\
(0.043)\end{array}$ & $\begin{array}{c}0.163 * * * \\
(0.034)\end{array}$ & $\begin{array}{c}0.172 \\
(0.121)\end{array}$ \\
\hline Violence & $\begin{array}{l}1.513 * * \\
(0.598)\end{array}$ & $\begin{array}{c}0.482 \\
(0.381)\end{array}$ & $\begin{array}{c}0.272 \\
(0.422)\end{array}$ & $\begin{array}{c}0.235^{* * *} * \\
(0.090)\end{array}$ & $\begin{array}{c}0.731 \\
(0.515)\end{array}$ \\
\hline GeoPolRisk & $\begin{array}{c}0.112 \\
(0.081)\end{array}$ & & & & \\
\hline CapFlowBoom & & $\begin{array}{c}3.395 \\
(4.227)\end{array}$ & & & \\
\hline CredBoom & & & $\begin{array}{c}38.786^{* * * *} \\
(12.217)\end{array}$ & & \\
\hline \#Spells & 95 & 95 & 95 & 131 & 67 \\
\hline LogLik & -3.880 & 3.729 & 5.753 & -13.370 & 8.893 \\
\hline SBIC & 85.18 & 74.51 & 70.46 & 109.61 & 53.69 \\
\hline
\end{tabular}

Notes: See notes in Tables 3-8. GeoPolRisk, CapFlowBoom and CredBoom correspond to the geopolitical risk index, capital flow booms and credit booms, respectively. All variables are measured as the average over each spell. Columns 4 and 5 report results for two different identification schemes of commodity price cycle phases. In Column 4, we set thresholds for commodity price booms (busts) equal to the median value of cumulative real commodity export price growth during upturns (downturns). In Column 5 , we identify commodity price booms (busts) as periods of consecutive upturns (downturns) in the real country-specific commodity export index, such that the cumulative real commodity export price growth exceeds (falls below) the top (bottom) quartile of the distribution. 
Table 11. Duration of commodity price busts - Sensitivity analysis.

\begin{tabular}{|c|c|c|c|c|c|}
\hline & $\begin{array}{l}\text { Geopolitical } \\
\text { risk }\end{array}$ & $\begin{array}{l}\text { Capital flow } \\
\text { boom-bust }\end{array}$ & $\begin{array}{c}\text { Credit } \\
\text { boom-bust }\end{array}$ & Median & Quartile \\
\hline & (1) & (2) & (3) & (4) & (5) \\
\hline \multirow[t]{2}{*}{$\gamma$} & 0.0001 & 0.0001 & 0.0001 & 0.0001 & 0.0001 \\
\hline & $(0.0001)$ & $(0.0001)$ & $(0.0002)$ & $(0.0002)$ & $(0.0001)$ \\
\hline \multirow[t]{2}{*}{$p$} & $5.794^{+, i}$ & $6.049^{+, i}$ & $5.804^{+, i}$ & $4.619^{+, i}$ & $5.077^{+, i}$ \\
\hline & $(0.526)$ & $(0.657)$ & $(0.571)$ & (0.301) & $(0.679)$ \\
\hline \multirow[t]{2}{*}{ Event } & $0.180 *$ & $0.330 * * *$ & $0.251^{* *}$ & 0.064 & 0.690 \\
\hline & $(0.102)$ & $(0.107)$ & (0.104) & $(0.120)$ & $(0.525)$ \\
\hline \multirow[t]{2}{*}{ Prev } & -0.535 & -0.433 & -0.612 & 0.180 & -0.453 \\
\hline & $(0.546)$ & $(0.552)$ & $(0.614)$ & $(0.206)$ & $(0.549)$ \\
\hline \multirow[t]{2}{*}{ DurPrev } & $0.034 * * *$ & 0.019 & $0.027 * *$ & $0.021 * *$ & $0.108 * * *$ \\
\hline & $(0.012)$ & $(0.012)$ & $(0.013)$ & (0.009) & $(0.041)$ \\
\hline \multirow[t]{2}{*}{ RGDPgr } & $1.454 * *$ & $1.356^{* *}$ & $1.625 * *$ & 0.356 & $1.572 * * *$ \\
\hline & $(0.610)$ & $(0.542)$ & $(0.664)$ & $(0.406)$ & $(0.544)$ \\
\hline \multirow[t]{2}{*}{ Inflation } & $-1.201 *$ & $-1.727 * * *$ & $-1.585^{*}$ & $-2.308 * * *$ & $-1.411 * * *$ \\
\hline & $(0.708)$ & $(0.667)$ & $(0.863)$ & $(0.687)$ & $(0.534)$ \\
\hline \multirow[t]{2}{*}{ InterestRate } & $1.921 * * *$ & $2.658 * * *$ & $2.433 * * *$ & $1.928 * * *$ & $3.005 * * *$ \\
\hline & $(0.249)$ & $(0.451)$ & $(0.388)$ & $(0.256)$ & $(0.600)$ \\
\hline \multirow[t]{2}{*}{ Liquidity } & $0.733 * * *$ & $0.927 * * *$ & $0.746 * * *$ & $0.454 * * *$ & $1.100 * * *$ \\
\hline & $(0.153)$ & $(0.200)$ & $(0.149)$ & (0.099) & $(0.266)$ \\
\hline \multirow[t]{2}{*}{ Uncertainty } & & 0.013 & 0.051 & $0.058 *$ & 0.010 \\
\hline & & $(0.055)$ & $(0.042)$ & $(0.032)$ & $(0.037)$ \\
\hline \multirow[t]{2}{*}{ Violence } & $0.633 * * *$ & $0.966^{* * *}$ & $0.721 * * *$ & $0.363^{*}$ & $0.807 * * *$ \\
\hline & $(0.109)$ & $(0.290)$ & $(0.205)$ & $(0.206)$ & $(0.166)$ \\
\hline GeoPolRisk & 0.009 & & & & \\
\hline \multirow{2}{*}{ CapFlowBust } & $(0.022)$ & & & & \\
\hline & & $\begin{array}{c}2.305 * * * \\
(0.732)\end{array}$ & & & \\
\hline \multirow[t]{2}{*}{ CredBust } & & & -2.856 & & \\
\hline & & & $(2.138)$ & & \\
\hline \#Spells & 127 & 127 & 127 & 158 & 80 \\
\hline LogLik & 16.38 & 22.22 & 18.26 & -15.41 & 2.391 \\
\hline SBIC & 49.59 & 42.76 & 50.67 & 116.88 & 74.09 \\
\hline
\end{tabular}

Notes: See notes in Tables 3-8. GeoPolRisk, CapFlowBoom and CredBoom correspond to the geopolitical risk index, capital flow booms and credit booms, respectively. All variables are measured as the average over each spell. Columns 4 and 5 report results for two different identification schemes of commodity price cycle phases. In Column 4, we set thresholds for commodity price booms (busts) equal to the median value of cumulative real commodity export price growth during upturns (downturns). In Column 5 , we identify commodity price booms (busts) as periods of consecutive upturns (downturns) in the real country-specific commodity export index, such that the cumulative real commodity export price growth exceeds (falls below) the top (bottom) quartile of the distribution. 
Table 12. Duration of commodity price normal times - Sensitivity analysis.

\begin{tabular}{|c|c|c|c|c|c|}
\hline & $\begin{array}{c}\text { Geopolitical } \\
\text { risk }\end{array}$ & $\begin{array}{l}\text { Capital flow } \\
\text { boom-bust }\end{array}$ & Credit boom-bust & Median & Quartile \\
\hline & (1) & $(2)$ & (3) & (4) & (5) \\
\hline \multirow[t]{2}{*}{$\gamma$} & 0.0001 & 0.0014 & 0.0011 & 0.0021 & 0.0019 \\
\hline & $(0.0001)$ & $(0.0013)$ & $(0.0012)$ & $(0.0018)$ & $(0.0018)$ \\
\hline \multirow[t]{2}{*}{$p$} & $2.146^{+, c}$ & $2.145^{+, c}$ & $2.220^{+, c}$ & $2.017^{+, \mathrm{c}}$ & $2.885^{+, i}$ \\
\hline & $(0.142)$ & $(0.134)$ & $(0.163)$ & (0.119) & $(0.295)$ \\
\hline \multirow[t]{2}{*}{ Event } & $0.749 * * *$ & $0.851 * * *$ & $0.950 * * *$ & $0.459 * * *$ & 0.420 \\
\hline & $(0.186)$ & $(0.146)$ & $(0.191)$ & $(0.156)$ & $(0.344)$ \\
\hline \multirow[t]{2}{*}{ Prev } & -0.266 & -0.240 & -0.086 & $0.700 * *$ & $2.030 * * *$ \\
\hline & $(0.310)$ & $(0.294)$ & $(0.244)$ & $(0.335)$ & $(0.547)$ \\
\hline \multirow[t]{2}{*}{ DurPrev } & -0.000 & 0.000 & 0.001 & -0.021 & 0.011 \\
\hline & $(0.014)$ & $(0.014)$ & $(0.013)$ & $(0.013)$ & $(0.010)$ \\
\hline \multirow[t]{2}{*}{ RGDPgr } & 0.343 & -0.202 & 0.213 & 0.185 & -0.183 \\
\hline & $(0.211)$ & $(0.493)$ & $(0.598)$ & $(0.362)$ & $(0.609)$ \\
\hline \multirow[t]{2}{*}{ Inflation } & $1.135 * *$ & $1.514 * * *$ & $2.015 * * *$ & $1.208 * *$ & 0.608 \\
\hline & $(0.528)$ & $(0.551)$ & $(0.687)$ & $(0.585)$ & $(1.046)$ \\
\hline \multirow[t]{2}{*}{ InterestRate } & $-0.684 * * *$ & $-0.739 * * *$ & $-1.147 * * *$ & $-0.616 * * *$ & -1.098 \\
\hline & $(0.214)$ & $(0.172)$ & $(0.358)$ & $(0.218)$ & $(0.737)$ \\
\hline \multirow[t]{2}{*}{ Liquidity } & -0.068 & -0.135 & $-0.190 * *$ & -0.083 & $-0.224 * *$ \\
\hline & $(0.054)$ & $(0.097)$ & $(0.087)$ & $(0.077)$ & $(0.101)$ \\
\hline \multirow[t]{2}{*}{ Uncertainty } & & $-0.031 *$ & $-0.036 * *$ & -0.011 & -0.002 \\
\hline & & $(0.017)$ & $(0.017)$ & $(0.015)$ & $(0.034)$ \\
\hline \multirow[t]{2}{*}{ Violence } & $-0.551 * * *$ & $-0.548 * * *$ & $-0.522 * * *$ & $-0.470 * * *$ & $-0.674 * * *$ \\
\hline & $(0.123)$ & $(0.140)$ & $(0.133)$ & $(0.144)$ & $(0.180)$ \\
\hline \multirow[t]{2}{*}{ GeoPolRisk } & -0.020 & & & & \\
\hline & $(0.020)$ & & & & \\
\hline \multirow[t]{2}{*}{ CapFlowBust } & & -0.483 & & & \\
\hline & & $(0.672)$ & & & \\
\hline \multirow[t]{2}{*}{ CredBust } & & & 1.883 & & \\
\hline & & & $(1.304)$ & & \\
\hline \#Spells & 133 & 133 & 133 & 125 & 98 \\
\hline LogLik & -104.0 & -103.25 & -101.71 & -104.7 & -50.27 \\
\hline SBIC & 291.08 & 294.53 & 290.68 & 291.58 & 178.48 \\
\hline
\end{tabular}

Notes: See notes in Tables 3-8. GeoPolRisk, CapFlowBoom and CredBoom correspond to the geopolitical risk index, capital flow booms and credit booms, respectively. All variables are measured as the average over each spell. Columns 4 and 5 report results for two different identification schemes of commodity price cycle phases. In Column 4, we set thresholds for commodity price booms (busts) equal to the median value of cumulative real commodity export price growth during upturns (downturns). In Column 5 , we identify commodity price booms (busts) as periods of consecutive upturns (downturns) in the real country-specific commodity export index, such that the cumulative real commodity export price growth exceeds (falls below) the top (bottom) quartile of the distribution. 


\section{List of Figures}

Figure 1. Commodity price booms, busts and normal times: Survival functions.

\section{Commodity price booms}

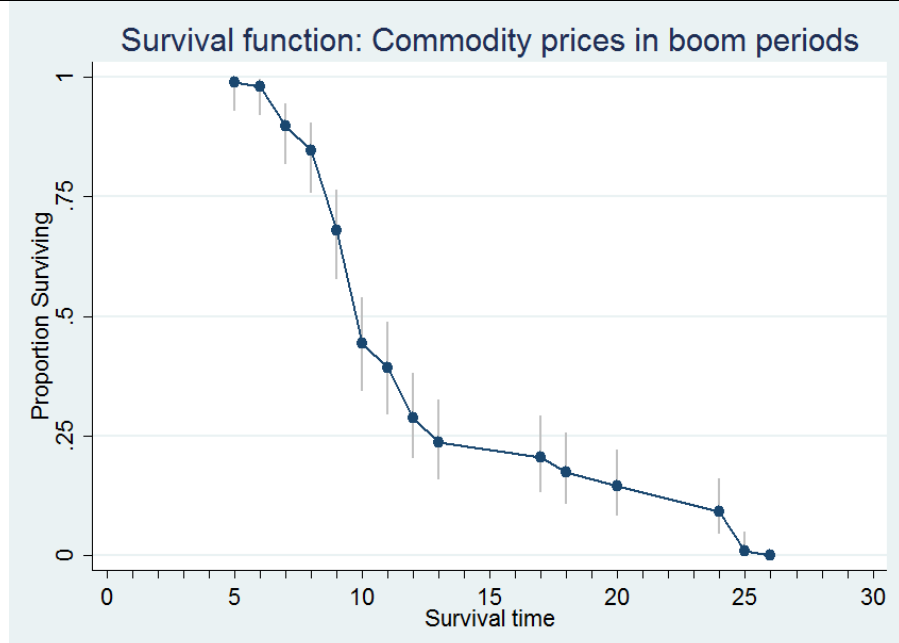

Commodity price busts

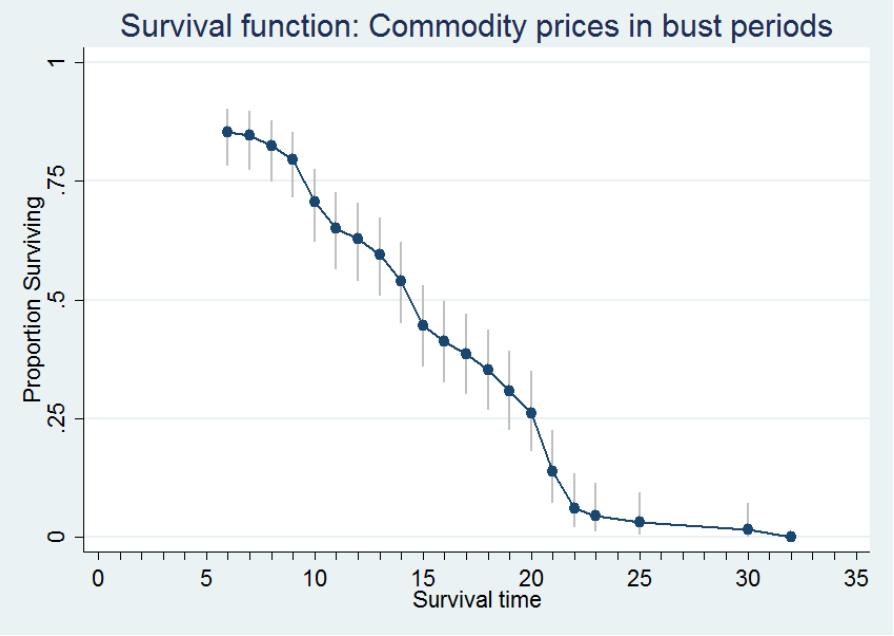

Normal times

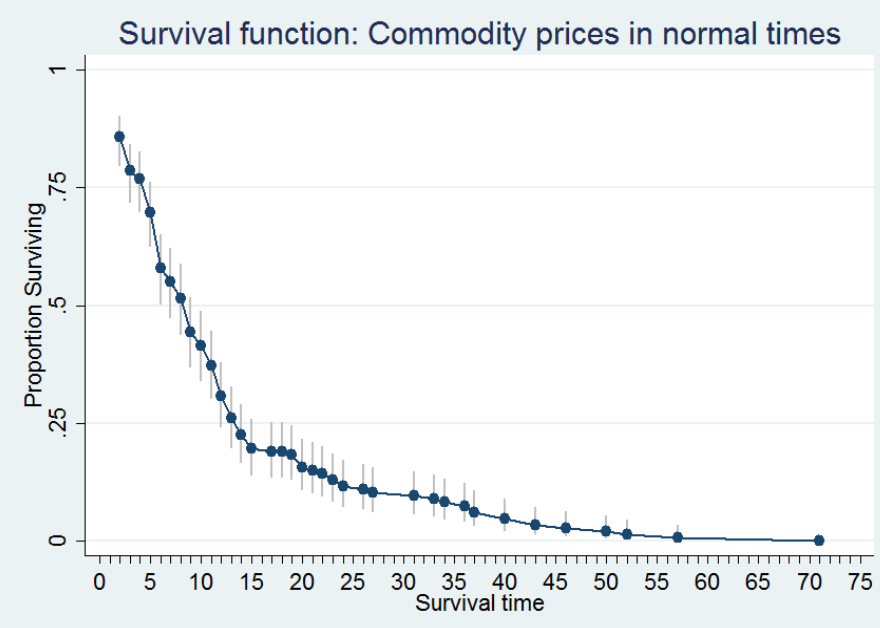

